\title{
Head in the clouds: a new dwarf frog species of the Physalaemus signifer clade (Leptodactylidae, Leiuperinae) from the top of the Brazilian Atlantic Forest
}

\author{
Fernando LEAL ${ }^{\circledR 1, *}$, Camila ZORNOSA-TORRES ${ }^{\circledR 2}$, Guilherme AUGUSTO-ALVES ${ }^{\circledR 3}$, \\ Simone DENA ${ }^{\circledR 4}$, Tiago Leite PEZZUTI ${ }^{\circledR 5}$, Felipe LEITE ${ }^{\circledR 6}$, \\ Luciana Bolsoni LOURENÇO ${ }^{\circledR 7}$, Paulo GARCIA ${ }^{\circledR 8}$ \& Luís Felipe TOLEDO ${ }^{\circledR 9}$ \\ ${ }^{1,5,8}$ Laboratório de Herpetologia, Instituto de Ciências Biológicas, Departamento de Zoologia, \\ Universidade Federal de Minas Gerais. Belo Horizonte, MG, Brazil. \\ 2,3,4,9 Laboratório de História Natural de Anfíbios Brasileiros (LaHNAB), Departamento de Biologia \\ Animal, Instituto de Biologia, Universidade Estadual de Campinas, Campinas, SP, Brazil. \\ ${ }^{4,9}$ Fonoteca Neotropical Jacques Vielliard (FNJV), Museu de Diversidade Biológica, \\ Instituto de Biologia, Universidade Estadual de Campinas, Campinas, SP, Brazil. \\ ${ }^{2,3}$ Programa de Pós-Graduação em Ecologia, Instituto de Biologia, Unicamp, Campinas, SP, Brazil. \\ ${ }^{6}$ Sagarana Lab, Instituto de Ciências Biológicas e da Saúde, Universidade Federal de Viçosa, \\ Campus Florestal, Florestal, MG, Brazil. \\ ${ }^{7}$ Laboratório de Estudos Cromossômicos, Departamento de Biologia Estrutural e Funcional, \\ Instituto de Biologia, Universidade Estadual de Campinas, Campinas, SP, Brazil.
}

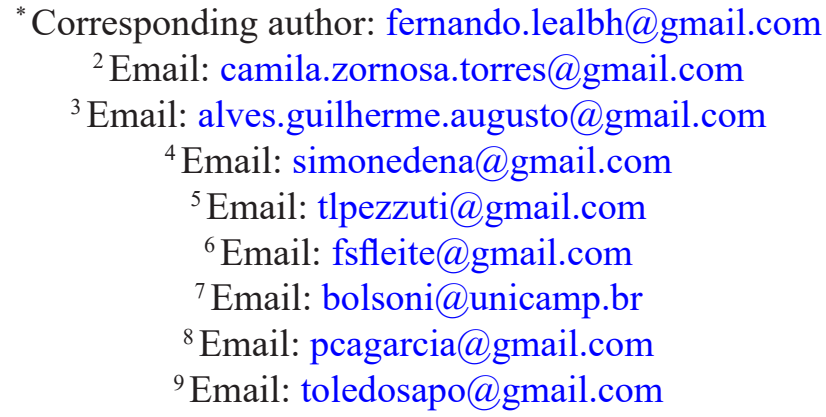

\footnotetext{
${ }^{1}$ urn:1sid:zoobank.org:author:6C9CE698-5A5B-4EF8-8378-117C51707990

${ }^{2}$ urn:lsid:zoobank.org:author:A0A31E69-A842-4E63-A930-5B5C0E6BBC94

${ }^{3}$ urn:lsid:zoobank.org:author:FC1879FC-6401-4A35-AA8F-D329EC85DBB8

${ }^{4}$ urn:1sid:zoobank.org:author:53AEC799-BD04-4D5E-AC7D-DCFE3A454983

${ }^{5}$ urn:lsid:zoobank.org:author:7279AC45-8032-4FA5-8D70-C8FF5F2B98AB

${ }^{6}$ urn:Isid:zoobank.org:author:BE0B4DCB-F8F5-4182-8AE2-2DAC714B4BEB

${ }^{7}$ urn:lsid:zoobank.org:author:C801BD8F-88F1-48CE-A1C5-F7B3A4852B59

${ }^{8}$ urn:lsid:zoobank.org:author:0BCFE0A1-5FBB-4175-9EE1-81606E6AB962

${ }^{9}$ urn:lsid:zoobank.org:author:2430A30A-DB39-4C75-9508-F9489557A223
}

Abstract. In an elevational gradient, the mountain top generally presents a reduced species diversity. However, it is there where we often find microendemic and quite often still undescribed species. That 
prediction is very common in underexplored Neotropical mountains, like those of the Caparaó National Park - a protected area that includes the highest peak of the Atlantic Forest, a megadiverse domain. Up in its top, we found a dwarf frog of the genus Physalaemus (Anura, Leptodactylidae, Leiuperinae), belonging to the $P$. signifer clade. After an integrative (morphological, bioacoustical, and genetic) analysis, we were able to describe it as a new species and found it to be sister to P. maculiventris. Due to its very restricted distribution at a site with extreme environmental conditions (which includes fires and frosts) and current instability in national environmental policy, we suggest this to be classified as an endangered species. A brief description of its natural history and the description of the species itself will now enable its proper conservation status categorization and the future planning for conservation actions.

Keywords. Anura, Physalaemus araxa, species description, systematics, taxonomy.

Leal F., Zornosa-Torres C., Augusto-Alves G., Dena S., Pezzuti T.L., Leite F., Lourenço B., Garcia P. \& Toledo L.F. 2021. Head in the clouds: a new dwarf frog species of the Physalaemus signifer clade (Leptodactylidae, Leiuperinae) from the top of the Brazilian Atlantic Forest. European Journal of Taxonomy 764: 119-151. https://doi.org/10.5852/ejt.2021.764.1475

\section{Introduction}

The Neotropical genus Physalaemus Fitzinger, 1876 (Leptodactylidae Werner, 1838: Leiuperinae Bonaparte, 1850) is one of the most speciose genera in Leptodactylidae, with 49 recognized species (Frost 2021). The genus comprises two large main clades, the Physalaemus signifer and Physalaemus cuvieri clades, both supported on the basis of molecular evidence (Lourenço et al. 2015). Although both clades still lack recognized morphological synapomorphies, species of the Physalaemus signifer clade may be identified by the presence of an arrow-shaped blotch on the dorsum of the body combined with the absence of tarsal tubercle (Leal et al. 2020). Moreover, the telocentric chromosome 11 has been suggested as putative synapomorphy of the P. signifer clade (Lourenço et al. 2015).

The Physalaemus signifer clade currently comprises 18 species: P. angrensis Weber, Gonzaga \& Carvalhoe-Silva, 2006; P. atlanticus Haddad \& Sazima, 2004; P. bokermanni Cardoso \& Haddad, 1985; P. caete Pombal \& Madureira, 1997; P. camacan Pimenta, Cruz \& Silvano, 2005; P. claptoni Leal, Leite, Costa, Nascimento, Lourenço \& Garcia, 2020; P. crombiei Heyer \& Wolf, 1989; P. deimaticus Sazima \& Caramaschi, 1988; P. erythros Caramaschi, Feio \& Guimarães, 2003; P. irroratus Cruz, Nascimento \& Feio, 2007; P. maculiventris (Lutz, 1925); P. moreirae (Miranda-Ribeiro, 1937); P. nanus (Boulenger, 1888); P. nattereri (Steindachner, 1863); P. obtectus Bokermann, 1966; P. rupestris Caramaschi, Carcerelli \& Feio, 1991; P. signifer (Girard, 1853); P. spiniger (Miranda-Ribeiro, 1926). Physalaemus nattereri, which is the sister taxon to the remainder species of the $P$. signifer clade (Lourenço et al. 2015), is widespread in open areas from the east of Paraguay and Bolivia to central and southeastern Brazil (Frost 2021). The species of the $P$. deimaticus group are restricted to highlands in quartzitic massifs of the Espinhaço and Mantiqueira Ranges, occurring in areas of campo rupestre (i.e., rupestrian grasslands) and hilltop forest fragments in the transition zone between the Atlantic Forest and Cerrado domains (Leal et al. 2020). The remainder species of the P. signifer clade occur in the Atlantic Forest (Lourenço et al. 2015).

The Mantiqueira Range, southeastern Brazil, is one of the largest and the highest Atlantic Forest mountain ranges, with altitudes reaching up to $2891 \mathrm{~m}$ a.s.l. (Alvarenga 1997), harboring an extremely diverse anuran fauna (Silva et al. 2018). In an elevational gradient, although the mountain tops generally present a reduced species richness (Rahbek 1995; Lomolino 2001), it is there where we often find narrow endemic and quite often still undescribed species (e.g., Leite et al. 2012; Walker et al. 2018; Santos et al. 2020). During field surveys in the highlands of the Serra do Caparaó (see Zornosa-Torres et al. 2020), 
we discovered a new species of the P. signifer clade. Herein, we describe it based on adult and larval morphology, bioacoustics, and genetics.

\section{Material and methods}

\section{Adult morphology}

Adult specimens were collected by active search, anesthetized, and euthanized with $10 \%$ lidocaine, fixed in $10 \%$ formalin, and preserved in $70 \%$ ethanol. Tissue samples were taken and maintained in $100 \%$ ethanol. Specimens used in the description are housed in the Brazilian amphibian collections (ZUECAMP) of the Museu de Diversidade Biológica (MDBio), Universidade Estadual de Campinas (Unicamp), Campinas, state of São Paulo (SP), and in the Centro de Coleções Taxonômicas (CCT), Universidade Federal de Minas Gerais (UFMG), Belo Horizonte, state of Minas Gerais (MG).

We took 11 morphometric measurements of adult specimens of the new species (Table 1) using digital calipers to the nearest $0.1 \mathrm{~mm}$. Ten measurements were taken in accordance with Watters et al. (2016): snout-vent length (SVL), head length (HL), head width (HW), eye diameter (ED), eye-nostril distance (END), internarial distance (IND), thigh length (THL), tibia length (TL), foot length (FL), and hand length (HAL). One measurement was taken by following Garcia et al. (2003): distance between the anterior margins of eyes (AMD). Finger notation, and shape of snout in dorsal and profile views were recorded according to Heyer et al. (1990). Measurements are presented in millimeters (mm).

Specimens used for comparisons (see Appendix I) are housed in the following Brazilian institutions: Museu de Diversidade Biológica (MDBio), Unicamp, Campinas, SP; Célio F.B. Haddad Amphibian Collection (CFBH), Universidade Estadual Paulista (Unesp), Rio Claro, SP; Museu de Zoologia (MZUSP), Universidade de São Paulo (USP), São Paulo, SP; Centro de Coleções Taxonômicas (CCT), Universidade Federal de Minas Gerais (UFMG), Belo Horizonte, MG; Museu de Zoologia João Moojen (MZUFV), Universidade Federal de Viçosa, Viçosa, MG; Coleção Zoológica do Museu de Biologia Professor Mello Leitão (MBML), Instituto Nacional da Mata Atlântica, Santa Teresa, state of Espírito Santo (ES); and Museu Nacional (MNRJ), Universidade Federal do Rio de Janeiro, Rio de Janeiro, state of Rio de Janeiro (RJ).

Supplementary morphological data used for comparisons were obtained from the original species descriptions and/or from other studies, as follows: Physalaemus angrensis (Weber et al. 2006); P. atlanticus (Haddad \& Sazima 2004); P. bokermanni (Cardoso \& Haddad 1985); P. caete (Pombal \& Madureira 1997); P. camacan (Pimenta et al. 2005); P. claptoni (Leal et al. 2020); P. crombiei (Heyer \& Wolf 1989); P. irroratus (Cruz et al. 2007); P. maculiventris (Bokermann 1962; Heyer et al. 1990); P. moreirae (Heyer 1985); P. nanus (Bokermann 1962); P. nattereri (Nascimento et al. 2005); P. obtectus (Bokermann 1966); P. signifer (Bokermann 1962); P. spiniger (Haddad \& Pombal 1998).

\section{Bioacoustics}

We recorded calling males in their natural habitats with a Sony PCM-M10 sound recorder and built-in microphones and a Marantz PMD 661 MKII recorder coupled to a Sennheiser ME 66 unidirectional microphone at a sample rate of $96 \mathrm{kHz}$, a sample size of 24 bits, and saved in WAV format. Recordings were deposited at Fonoteca Neotropical Jacques Vielliard (FNJV), MDBio, Unicamp, Campinas, SP (FNJV 34611, 34616, 34618, 34631-33, 34644). We also placed four adult males (ZUEC-AMP 2411724120 ) in a plastic aqua-terrarium, with vegetation and water mimicking its natural habitat, and recorded vocalizations in the laboratory, at room temperature, uninterruptedly from 16:00 to 23:00 using an autonomous recorder (Song Meter SM3 - Wildlife Acoustics) at a sample rate of $24 \mathrm{kHz}$, sample size of 16 bits, and WAV format. These recordings were also deposited in FNJV (FNJV 37444-37447, 37449). Prior to analyses, all recordings' frequencies lower than $250 \mathrm{~Hz}$ were filtered out (Butterworth function, 
in Adobe Audition CC). Calls were normalized, removing DC offset (mean amplitude displacement from zero), centering on 0.0 vertically, and to the maximum amplitude of $-3.0 \mathrm{~dB}$, using the software Adobe Audition CC. We analyzed the recordings of advertisement calls in Raven Pro ver. 1.4 (Center for Conservation Bioacoustics 2011) using the following configurations: $90 \%$ brightness, $70 \%$ contrast, and Fast Fourier Transform window size (FFT) of 512. Aggressive calls were analyzed in Raven Pro ver. 1.6 (Center for Conservation Bioacoustics 2019), using the following configurations: 53\% brightness, $70 \%$ contrast, and FFT of 512 .

We followed the terminology and definitions presented by Köhler et al. (2017), using the note-centered approach, in which one entire series would be a call, and each sound unit a note, that could be further subdivided into pulses. A note is defined as a subunit of the call with $100 \%$ amplitude modulation and short intervals between them. Note and call intervals were considered as equal or longer than the length of the entire note or call, respectively (Köhler et al. 2017). We measured the following acoustic parameters (Tables 2-3): call duration, note duration, intercall interval, internote interval, call rate (only for advertisement call), note rate (number of notes per call), dominant frequency (peak frequency function in Raven), minimum frequency (frequency 5\% function in Raven), maximum frequency (frequency 95\% function in Raven), and frequency bandwidth (only for advertisement call; defined as the difference between frequency $95 \%$ and frequency 5\%; Charif et al. 2010). Spectral parameters were measured in the spectrogram and temporal parameters were measured in the oscillogram.

We used field recordings from seven males to describe advertisement calls (FNJV 34611, 34616, 34618, 34631-33, 34644). To describe aggressive calls, we analyzed recordings (FNJV 37444-37447, 37449) from four males, including those recordings made from the aqua-terrarium. For comparisons, we analyzed advertisement call recordings of individuals identified as $P$. maculiventris from three different localities in the state of São Paulo: Estação Biológica de Boracéia, Salesópolis (FNJV 33756), Paranapiacaba (FNJV 31815), and São Paulo Zoo, São Paulo (FNJV 31988); and those recordings reported for P. maculiventris in Hepp \& Pombal (2020). For comparisons with other congeneric species, we used data obtained from Weber et al. (2006) for P. atlanticus, P. angrensis, P. bokermanni, P. crombiei, P. moreirae, and P. signifer; from Leal et al. (2020) for P. claptoni and P. rupestris; from Carvalho et al. (2020) for P. caete, and from Pimenta et al. (2005) for P. camacan.

\section{Natural history}

We recorded 24 hours of vocal activity using an autonomous recorder (Song Meter SM3, Wildlife Acoustics) situated at the margin of the Lagoa da Sombra (Supp. file 1, arrow indicates the autonomous recorder), where males were observed calling. Recordings were made continuously from midday 11 October 2017 to midday of the next day. Lower frequencies filter and calls normalizations were done as reported above in the bioacoustics section. We counted the number of calls of each hour using the interactive detectors (Band Limited Energy Detector) on the software Raven Pro ver. 1.5 (Center for Conservation Bioacoustics 2011) using the following parameters: minimum frequency of $1 \mathrm{kHz}$; maximum frequency of $4 \mathrm{kHz}$; minimum duration of $0.202 \mathrm{~s}$; maximum duration of $0.501 \mathrm{~s}$; minimum separation interval of $0.053 \mathrm{~s}$. After running the automatic detection, we visually corrected the selections and counted the number of calls per hour. Visual configurations adopted were: $50 \%$ brightness, $70 \%$ contrast, and FFT of 512. Analyzed calls may be for one or several individuals, as it was not possible to distinguish the number of calling males. With this information we plotted male vocal activity (number of calls/hour) along 24 hours and fitted a normal distribution.

\section{Tadpoles}

Tadpoles were collected in the same pond where the adults were found, euthanized in $5 \%$ lidocaine solution, then preserved in 10\% formalin. Voucher lots are housed in the collection of Museu de Diversidade Biológica, Unicamp, Campinas (ZUEC-AMP 24214). For qualitative external morphological 
characterization, we analyzed 18 tadpoles at stages 35-38 of Gosner (1960). Descriptions, measurements, and proportions of tadpole external morphology are based on a subset of nine tadpoles restricted to stages 37-38 (ZUEC-AMP 24214). In the description, the ratios between measurements are expressed as ranges. We photographed each tadpole in lateral, dorsal, and ventral views using an adjustable platform to support tadpoles immersed in water (Schacht \& McBrayer 2009). All measurements (Table 4) were taken to the nearest $0.1 \mathrm{~mm}$ with the aid of ImageJ ver. $1.50 \mathrm{~b}$ (Schneider et al. 2012). Terminology follows Altig \& McDiarmid (1999). Measurements follow Altig \& McDiarmid (1999) for body length (BL), internarial distance (IND), interorbital distance (IOD), maximum tail height (MTH), tail length (TAL), total length (TL), tail muscle height (TMH), and tail muscle width (TMW); Lavilla \& Scrocchi (1986) for body height (BH), body width (BW), body width at eye level (BWE), body width at narial level (BWN), eye diameter (ED), eye-nostril distance (END), eye-snout distance (ESD), narial diameter (ND), nostrilsnout distance (NSD), oral disc width (ODW), and snout-spiracular distance (SSD); Grosjean (2005) for dorsal fin height (DFH) and ventral fin height (VFH); Lins et al. (2018) for length of anterior gap on marginal papillae (AGL), dorsal fin insertion angle (DFIA), oral-disc position (ODP), spiracle length (SL), spiracular-venter distance (SVD), and vent tube length (VTL).

For the comparisons with the known tadpoles of the Physalaemus signifer clade (sensu Lourenço et al. 2015), we used the original tadpole descriptions of $P$. angrensis (Ruggeri et al. 2011), P. atlanticus (Haddad \& Sazima 2004), P. bokermanni (Cardoso \& Haddad 1985), P. caete (Pombal \& Madureira 1997), P. camacan (Pimenta et al. 2005), P. crombiei (Ruggeri \& Weber 2012), P. erythros (Baêta et al. 2007), P. irroratus (Cruz et al. 2007), P. maculiventris (Bokermann 1963), P. moreirae (Provete et al. 2011), P. nanus (Ceron \& Santana 2017), P. rupestris (Nascimento et al. 2001), P. signifier (Weber \& Carvalho-e-Silva 2001), P. spiniger (Haddad \& Pombal 1998), and the comparative study of Ruggeri \& Weber (2012).

\section{Karyotype}

We obtained metaphases from testicular cell suspensions of two males and intestinal epithelium suspension of one tadpole for the karyotype description. The individuals were anesthetized with $2 \%$ lidocaine $(50 \mathrm{mg} / \mathrm{g}$ body weight - cutaneous administration) after pre-treatment in vivo with $2 \%$ colchicine $(0.02 \mathrm{ml} / \mathrm{g}$ body weight) for $4 \mathrm{~h}$. Chromosome preparations were obtained following King \& Rofe (1976) with modifications from Gatto et al. (2018) and Schmid et al. (1979), stained with 10\% Giemsa solution and C-banded according to King (1980). We took chromosome measurements from nine metaphases (Table 5) using DRAWID (DRAWing IDiogram; Kirov et al. 2017), and the chromosomes were classified following Green \& Sessions (1991).

\section{Phylogenetic and genetic distance analyses}

To assess the interspecific phylogenetic relationships of the new species, we conducted a phylogenetic analysis based on mitochondrial DNA sequences that comprised 12S rRNA, tRNA-val, and 16S rRNA genes (H1 fragment sequences). Our dataset included one specimen of the new species (ZUEC-AMP 24120) and representatives of other 44 species of Physalaemus, for which DNA sequences were available in the GenBank (Supp. file 2). Because the new species is closely related to P. maculiventris, we improved the sample of this species by adding one topotype (Paranapiacaba, SP, Brazil), one specimen from Iporanga (SP, Brazil), and another from Curucutu (Serra do Mar State Park, Núcleo Curucutu, São Paulo, SP, Brazil) (Supp. file 2). As outgroup, we included nine species of Engystomops Jiménez de la Espada, 1872 and one of Edalorhina Jiménez de la Espada, 1870 (for details, see Supp. file 2), which have been inferred as being closely related to Physalaemus (Fouquet et al. 2013; Lourenço et al. 2015).

To obtain the DNA sequences from the new species and P. maculiventris specimens, genomic DNA was extracted from liver tissue preserved in 100\% ethanol using a TNES protocol (as performed by Lourenço et al. 2015). Polymerase chain reactions (PCR) with the primer pairs MVZ 59 (Graybeal 1997) - Titus I 
(Titus 1992) and 12L13 (Feller \& Hedges 1998) - 16Sbr (Palumbi et al. 2002) were performed to amplify the H1 mitochondrial fragment of interest. The PCR products were purified using the Wizard SV Gel and PCR Clean-up System (Promega). The resulting fragments were bidirectionally sequenced using the BigDye Terminator kit (Applied Biosystems), with the above-mentioned primers and the primers MVZ50 (Graybeal 1997), 16SL2a (Hedges 1994), 16H10 (Hedges 1994), and 16Sar (Palumbi et al. 2002). The nucleotide sequences were read using an ABI 3730xL DNA Analyzer automatic sequencer (Applied Biosystems). Full-length sequences were obtained after assembling multiple reads of each specimen using the BioEdit Sequence Alignment Editor software (Hall 1999).

The nucleotide sequences were aligned using MAFFT ver. 7 (Katoh et al. 2019; https://mafft.cbrc.jp/alignment/server/), under the G-INS-i strategy. The resulting data matrix, composed of 71 terminals (Supp. file 2) and 2426 characters, was used to infer phylogenetic trees under maximum parsimony criterion using the software TNT ver. 1.1 (Goloboff et al. 2008) and by Bayesian analysis in MrBayes ver. 3.2.5 (Ronquist et al. 2011). To find the most parsimonious trees, we used a heuristic search method performed through the option 'New Technology Search', including sectorial searches, ratchet, tree drifting, and tree fusing. The best length was hit 100 times from 5 random seeds. Gaps were considered as fifth character state. A strict consensus cladogram was obtained from the 20 most parsimonious trees (with 6640 steps) and bootstrap values of the branches were calculated using traditional search method and 1000 pseudoreplicates. The Bayesian analysis was executed with the GTR $+\mathrm{I}+\mathrm{G}$ model, which was inferred in MrModeltest ver. 2.3 (Nylander 2004) as the best-fitting model for our dataset. Two simultaneous analyses were run, each with four chains (three heated and one cold) and 2 million generations. One tree was sampled every 100 generations. Consensus topology (50\% majority-rule consensus tree) and posterior probabilities were produced after discarding the first $25 \%$ of the trees generated. The average standard deviation of split frequencies (ASDSF) value was below 0.01 and the Potential Scale Reduction Factor values were approximately 1.000 . The stabilization of posterior probabilities was checked using Tracer ver. 1.6 (Rambaut et al. 2014). The inferred cladograms were edited using the software FigTree ver. 1.4.3 (http://tree.bio.ed.ac.uk/software/figtree). Uncorrected genetic distances ( $p$-distances) were estimated from the 12SrRNA, tRNA-val-16SrRNA fragment and also the partial segment of 16S rRNA gene flanked by the primers 16Sar and 16Sbr (Table 6), which has been largely used for evaluating interspecific variation (see Fouquet et al. 2007 and Lyra et al. 2017). For this analysis, we used the software MEGA ver. 7.0. (Kumar et al. 2016) and gaps were not considered in pairwise comparisons.

\section{Results}

Class Amphibia Gray, 1825

Order Anura Fischer Von Waldheim, 1813

Family Leptodactylidae Werner, 1896 (1838)

Subfamily Leiuperinae Bonaparte, 1850

Genus Physalaemus Fitzinger, 1826

Physalaemus araxa sp. nov.

urn:1sid:zoobank.org:act:5F59A249-8820-4EAD-8BDA-9603A8F3B4EE

Figs 1-4, 5D, 6-7; Tables 1-6

Physalaemus sp. (aff. maculiventris) - Zornosa-Torres et al. 2020: 4-6, 12-13.

\section{Type material}

Holotype

BRAZIL • adult ${ }^{\top}$; state of Espírito Santo, municipality of Ibitirama, Parque Nacional do Caparaó, Lagoa da Sombra; $20.421778^{\circ} \mathrm{S}, 41.802500^{\circ} \mathrm{W} ; 2505 \mathrm{~m}$ a.s.1.; datum WGS84; 5 Oct. 2017; C. Zornosa-Torres, G. Augusto-Alves and S. Dena leg.; ZUEC-AMP 24095. (Figs 1-2; Table 1) 


\section{Paratypes}

BRAZIL $\bullet 6$ adult $\hat{\partial} \bar{o}$; same collection data as for the holotype; ZUEC-AMP 24094, 24096 to 24100 - 2 adult $\widehat{\partial}$; ; same locality as for the holotype; 26 Nov. 2014; F.S.F. Leite leg.; UFMG 17250, 17251

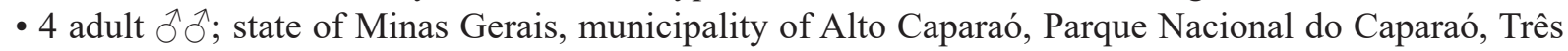
Lagoas; $20.430972^{\circ} \mathrm{S}, 41.802611^{\circ} \mathrm{W}$; $2505 \mathrm{~m}$ a.s.1.; datum WGS84; 10 Oct. 2017; C. Zornosa-Torres, G. Augusto-Alves and S. Dena leg.; ZUEC-AMP 24117 to 24120.

\section{Additional material examined}

BRAZIL - 3 juveniles raised in captivity from wild-collected tadpoles; same locality as for the holotype; 25 Jan. 2018; C. Zornosa-Torres, G. Augusto Alves and C. Nunes de Almeida leg.; ZUEC-AMP 24403 to $24405 \cdot 1$ lot of 25 tadpoles; state of Minas Gerais, municipality of Alto Caparaó, Parque Nacional do Caparaó, Três Lagoas; $20.430972^{\circ} \mathrm{S}, 41.802611^{\circ} \mathrm{W}$; $2505 \mathrm{~m}$ a.s.1.; datum WGS84; 6 Dec. 2017; C. Zornosa-Torres, G. Augusto Alves and R. Santos leg.; ZUEC-AMP 24214.

\section{Diagnosis}

Physalaemus araxa sp. nov. is distinguishable from all congeneric species by having the following combination of character states: (1) presence of an arrow-shaped blotch on the dorsum of the body (Fig. 1A); (2) tarsal tubercle absent (Fig. 2D); (3) gular region and chest predominantly yellow in live individuals, pale cream in preserved specimens (Figs 1B, 3B-C); (4) belly with dark vermiculation pattern on a pale cream, slightly bluish background in live individuals (Figs 1B, 3C); (5) lack of aposematic coloration on ventral surface of hand and foot in live individuals (Fig. 3C); (6) intermediate size within the P. signifer clade (adult male $\mathrm{SVL}=17.4-21.5 \mathrm{~mm}$, Table 1); (7) presence of brown, divided, nuptial pad in males (Figs 1A, 2C); (8) supernumerary tubercles on foot absent (Fig. 2D); (9) tarsal fold absent (Fig. 2D); (10) texture of posterior region of belly and ventral surface of thigh smooth (Fig. 1B); (11) advertisement call duration from 69-304 ms (Table 2); (12) tadpole with a proportionally large body BL/TL $=0.39-0.43$ (Table 4); (13) dextral vent tube (Fig. 6G); (14) dorsal and ventral fins of the same height (Fig. 6A, H; Table 4); (15) tail tip broadly rounded (Fig. 6A, H); (16) presence of submarginal papillae arranged in small rows; (17) A2 tooth row conspicuously longer than A1 (Fig. 6D); (18) absence of a dermal fold at the body-tail junction; (19) external margins of fins slightly convex (Fig. 6A, H); (20) gular region of tadpole convex.

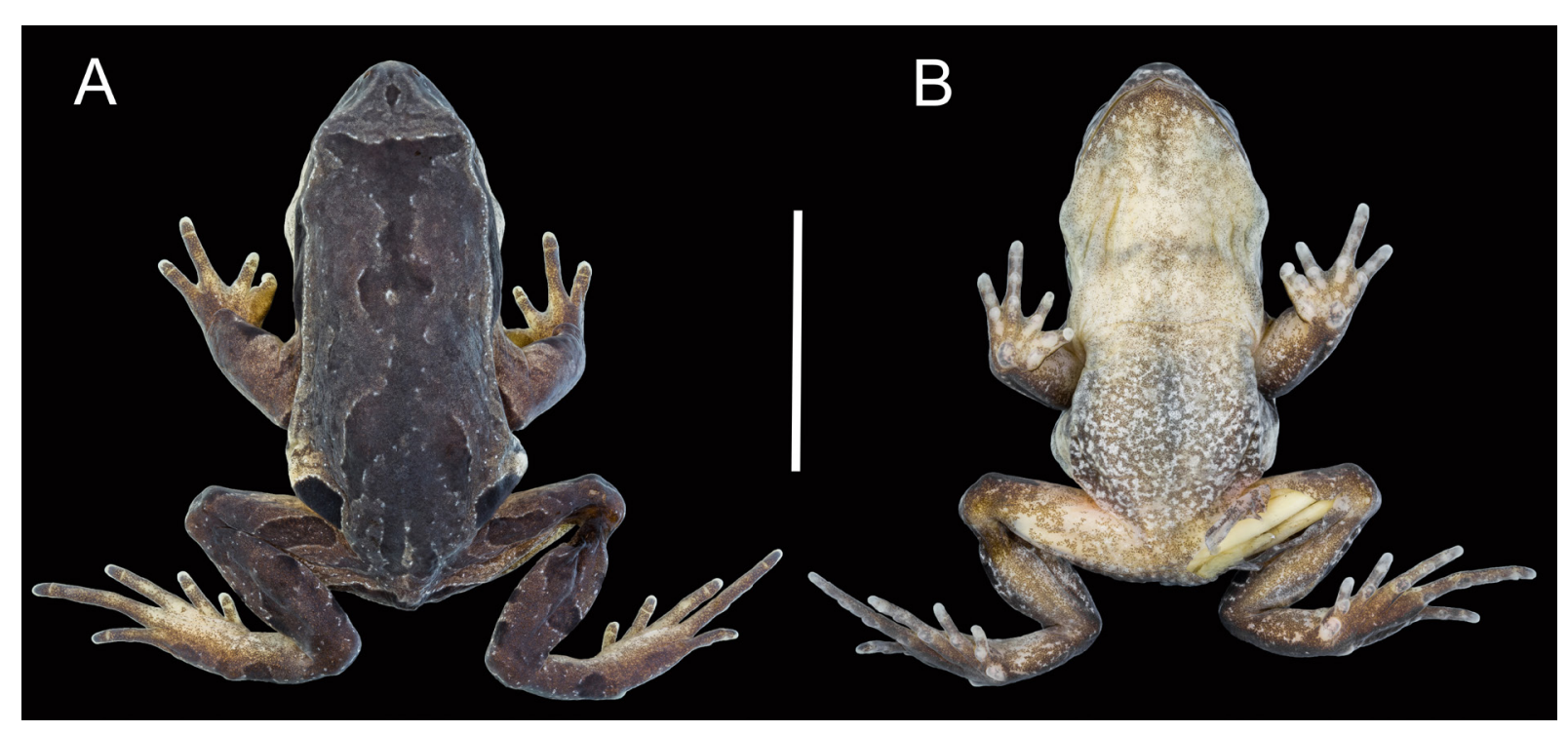

Fig. 1. Physalaemus araxa sp. nov., holotype, adult $\hat{\partial}$, SVL $21 \mathrm{~mm}$ (ZUEC-AMP 24095). A. Dorsal view. B. Ventral view. Scale bar $=5 \mathrm{~mm}$. 


\section{Comparison with other species}

Physalaemus araxa sp. nov. may be set apart from all the species of the Physalaemus cuvieri clade (sensu Lourenço et al. 2015) by simultaneously having (1) the presence of an arrow-shaped blotch on the dorsum of the body and (2) absence of tarsal tubercle (Leal et al. 2020). (3) The gular region and chest predominantly yellow-colored in live individuals, pale cream in preserved specimens, distinguish the new species from all the other species of the $P$. signifer clade (gular region and chest predominantly dark brown in live and preserved individuals of those species). Additionally, live individuals of Physalaemus araxa sp. nov. have (4) belly with dark vermiculation on a pale cream, slightly bluish background, distinguishing it from P. angrensis, P. atlanticus, P. nanus, and P. spiniger (belly with flashy orange blotches in those species), from $P$. maculiventris (which has a pale chest and belly, with posterior region of belly and ventral surface of thigh showing bold black blotches), and from P. obtectus (which has belly with flashy red blotches). (5) The lack of aposematic coloration on ventral surface of hand and foot in live individuals distinguishes the new species from $P$. angrensis, $P$. atlanticus, $P$. spiniger (orange aposematic coloration

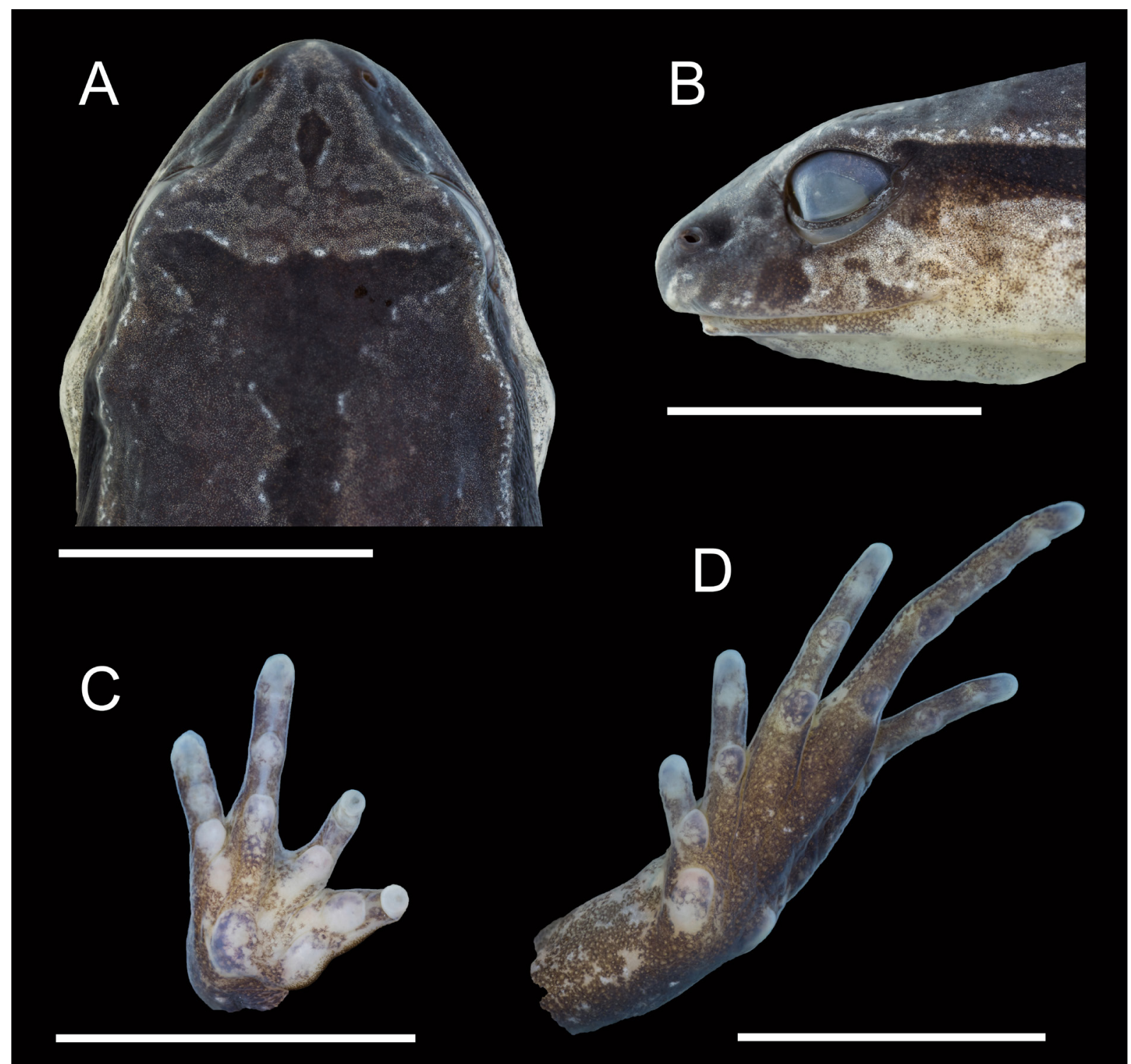

Fig. 2. Physalaemus araxa sp. nov., holotype, adult $\widehat{\jmath}$ (ZUEC-AMP 24095). A. Head, dorsal view. B. Head, lateral view. C. Right hand, ventral view. D. Right foot, ventral view. Scale bars $=2 \mathrm{~mm}$. 
present on ventral surface of hand and foot in live individuals of those species) and from $P$. claptoni, P. deimaticus, P. erythros (red aposematic coloration present on ventral surface of hand and foot in live individuals of those species). (6) By having adult males of intermediate size within the $P$. signifer clade $(\mathrm{SVL}=17.4-21.5 \mathrm{~mm}), P$. araxa sp. nov. is set apart from $P$. bokermanni (which is smaller, $\mathrm{SVL}=$ $15.3-17.0 \mathrm{~mm}$ ) and from P. caete, P. camacan, P. moreirae, P. nattereri, and P. obtectus (which are larger, combined $\mathrm{SVL}=22.3-50.6 \mathrm{~mm}$ ). (7) The presence of a brown, divided, nuptial pad in males distinguishes P. araxa sp. nov. from P. claptoni (which has a nuptial pad not divided) and from P. rupestris (which has a white cream nuptial pad). (8) The lack of supernumerary tubercles on foot distinguishes $P$. araxa sp. nov. from $P$. angrensis, $P$. caete, $P$. camacan, $P$. crombiei, $P$. irroratus, $P$. moreirae, $P$. signifer, and $P$. spiniger (supernumerary tubercles present on the foot in those species). (9) The lack of a tarsal fold distinguishes $P$. araxa sp. nov. from $P$. atlanticus, $P$. bokermanni, $P$. camacan, $P$. crombiei, $P$. irroratus, $P$. nanus, $P$. obtectus, $P$. signifier, and $P$. spiniger (tarsal fold present in those species). (10) Texture of posterior region of belly and ventral surface of thigh smooth in $P$. araxa sp. nov. distinguishes it from $P$. camacan and $P$. irroratus (posterior region of belly and ventral surface of thigh granulated in those species). (11) The duration of the advertisement call of the new species ranges from 69-304 ms, setting
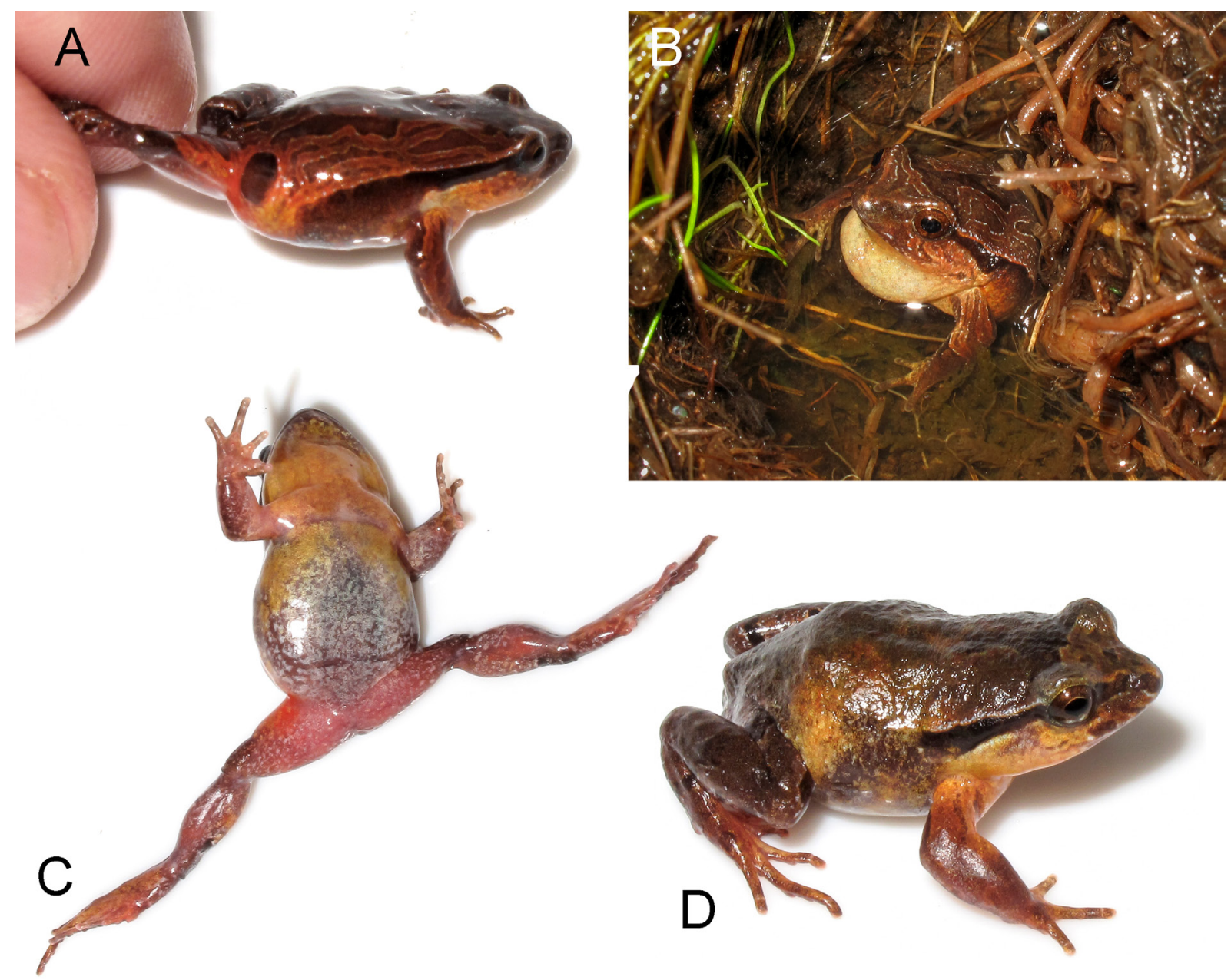

Fig. 3. Color in live paratypes of Physalaemus araxa sp. nov. A. ZUEC-AMP 24119 (paratype), evidencing the color of inguinal region. B. ZUEC-AMP 24120 (paratype), in an upright posture with vocal sac slightly inflated, photographed in situ; notice the contrast of the yellow vocal sac with the background. C-D. ZUEC-AMP 24098 (paratype), evidencing ventral and dorsolateral colors; notice the distribution of yellow pigmentation ventrally and laterally. 
Table 1. Morphometric measurements (in $\mathrm{mm}$ ) and proportions of the Physalaemus araxa sp. nov. type series. Values are presented as range (average \pm SD). See Material and methods for abbreviations.

\begin{tabular}{lcc}
\hline Measurement & Holotype (male) & Paratypes (12 males) \\
\hline SVL & 21.0 & $17.4-21.5(19.6 \pm 1.1)$ \\
HL & 7.5 & $6.6-7.6(7.2 \pm 0.3)$ \\
HW & 7.9 & $6.9-7.9(7.3 \pm 0.3)$ \\
ED & 1.9 & $1.8-1.9(1.9 \pm 0.03)$ \\
END & 1.8 & $1.5-1.9(1.7 \pm 0.1)$ \\
AMD & 3.8 & $3.3-3.8(3.6 \pm 0.1)$ \\
IND & 1.7 & $1.5-1.7(1.6 \pm 0.1)$ \\
THL & 8.3 & $7.2-8.2(8.0 \pm 0.3)$ \\
TL & 8.1 & $7.1-8.0(7.7 \pm 0.3)$ \\
FL & 12.7 & $11.2-12.6(12.1 \pm 0.4)$ \\
HAL & 4.8 & $3.9-4.7(4.5 \pm 0.2)$ \\
HL/SVL & 0.36 & $0.35-0.4(0.37 \pm 0.01)$ \\
HW/SVL & 0.38 & $0.35-0.4(0.37 \pm 0.01)$ \\
HL/HW & 0.95 & $0.95-1.0(0.98 \pm 0.02)$ \\
THL/SLV & 0.4 & $0.38-0.45(0.41 \pm 0.02)$ \\
TL/SLV & 0.39 & $0.37-0.41(0.39 \pm 0.01)$ \\
END/ED & 0.95 & $0.79-0.97(0.9 \pm 0.05)$ \\
\hline
\end{tabular}

it apart from P. angrensis, P. atlanticus, P. bokermanni, P. caete, P. camacan, P. claptoni P. crombiei, $P$. moreirae, $P$. rupestris, and $P$. signifer (which have longer advertisement calls, combined minimum advertisement call duration from 324-2,130 ms). (12) Tadpoles of $P$. araxa sp. nov. have a proportionally larger body $(\mathrm{BL} / \mathrm{TL}=0.39-0.43)$, differing from those of $P$. atlanticus, $P$. bokermanni, $P$. maculiventris, P. moreirae, and P. spiniger ( 0.34 in P. atlanticus, 0.35 in P. bokermanni, 0.33 in P. maculiventris, $0.27-$ 0.37 in $P$. moreirae, 0.37 in $P$. signifer, 0.34 in $P$. spiniger). (13) Tadpoles with dextral vent tube distinguish the new species from $P$. atlanticus, $P$. caete, $P$. camacan, $P$. nanus, $P$. rupestris, and $P$. spiniger (vent tube medial in those species). (14) By presenting dorsal and ventral fins of the same height tadpoles of $P$. araxa sp. nov. differ from those of $P$. angrensis, $P$. atlanticus, $P$. caete, $P$. camacan, P. crombiei, $P$. erythros, $P$. irroratus, $P$. moreirae, $P$. nanus, $P$. rupestris, $P$. signifer, and $P$. spiniger (dorsal fin higher than ventral one in those species) and from $P$. caete (which has dorsal fin lower than ventral one). (15) The broadly rounded tail tip also differs tadpoles of $P$. araxa sp. nov. from most species of the $P$. signifer clade, such as $P$. atlanticus, $P$. bokermanni, $P$. caete, $P$. camacan, $P$. crombiei, $P$. maculiventris, $P$. spiniger (tail tip pointed in those species) and $P$. angrensis, P. erythros, P. irroratus, P. moreirae, P. nanus, P. rupestris, $P$. signifier (tail tip nearly rounded in those species). (16) Tadpoles presenting submarginal papillae arranged in small rows set $P$. araxa sp. nov. apart from the remaining species of the $P$. signifer clade (which have submarginal papillae scattered in the lateral portions of the oral disc), except from P. erythros which has a similar condition. (17) The A2 tooth row conspicuously longer than A1 distinguishes tadpoles of $P$. araxa sp. nov. from those of $P$. atlanticus, $P$. bokermanni, P. camacan, $P$. erythros, $P$. maculiventris, and $P$. moreirae (A1 $=\mathrm{A} 2$ in those species) and from $P$. angrensis, $P$. caete, and $P$. spiniger $(\mathrm{A} 1>\mathrm{A} 2$ in those species). Additionally, tadpoles of $P$. araxa sp. nov. also differ from those of $P$. maculiventris by (18) the absence of a dermal fold at the body-tail junction (dermal fold present in P. maculiventris), by (19) the external margins of the fins slightly convex (fins markedly convex in P. maculiventris) and by (20) the gular region convex (gular region straight in P. maculiventris).

\section{Etymology}

The specific epithet 'araxa', is the combination of the Tupi-Guarani indigenous language words 'ara' (meaning 'world') and 'eça' (meaning 'to see') meaning 'the first place where the sun can be seen', in 
reference to the sunshine view on the top of hills (Chiaradia 2008). Also used to indicate the highest mountain in a landscape. That is the specific case of the type locality of Physalaemus araxa sp. nov., found on the mountaintop of the highest hill of the Atlantic forest.

\section{Description}

Holotype (ZUEC-AMP 24095)

Adult male (Figs 1-2), SVL $21.0 \mathrm{~mm}$. Head slightly wider than long. Head width $38.0 \% \mathrm{SVL}$ and length $36.0 \%$ SVL. Snout rounded in dorsal view and rounded to truncated in lateral view (Fig. 2AB). Canthus rostralis distinct, rounded; loreal region slightly concave. Snout protruding beyond lower jaw. Nostril dorsolaterally oriented, faintly protruding. Internarial region flat; top of the head slightly concave. Eye slightly prominent, anterolaterally oriented, its diameter $5 \%$ larger than END. Tympanum indistinct externally. Supratympanic fold distinct, thick, extending from the posterior corner of the eye to the shoulder. Dentigerous process of vomer absent. Premaxillary and maxillary teeth absent. Choanae rounded, separated from each other by a distance as large as four times its diameter. Tongue elongated, constricted on its anterior third, wider on its posterior half, free around lateral and posterior margin. Vocal slit present, longitudinal, originating on the sides of the tongue in its anterior third, and extending towards the corner of the mouth. Vocal sac single and subgular, faintly differentiated externally. Dorsolateral fold present, weakly distinct, from the posterior corner of the eye to the inguinal region. Forearm hypertrophied in relation to upper arm; upper arm slender, short. Fingers thick, without webs, relative lengths I $<$ II $=$ III $<$ IV; finger tips not expanded. Proximal subarticular tubercles large, simple, prominent, and rounded; distal subarticular tubercles present on fingers III and IV, approximately of the same size as the proximal ones; supernumerary tubercles large, rounded, low, more distinct in the left hand. Inner and outer metacarpal tubercles ovoid, large, prominent. Nuptial pad divided, densely covered by dark keratinized spicules, present on the dorsal and lateral surfaces of the thumb (except for the distal phalange) and on the internal surface of the internal metacarpal tubercle. Tibia length 39\% SVL; foot length $60 \%$ SVL. Toes thick, without webs, relative lengths I $<$ II $=\mathrm{V}<\mathrm{III}<\mathrm{IV}$; toe tips not expanded. Subarticular tubercles distinct, simple, prominent, and rounded; supernumerary tubercles absent. Tarsal fold absent; tarsal tubercle absent. Inner metatarsal tubercle distinct, ovoid; outer metatarsal tubercle distinct, rounded. Inguinal gland well developed, oval. Cloacal opening directed posteriorly at upper level of thighs. Region below the cloaca with low and faintly distinct tubercles scattered, encroaching the thighs on its posteroventral edge, where tubercles become increasingly less distinct. In preservative, texture of ventral, lateral, hidden, and dorsal surfaces are smooth. Measurements of the holotype in Table 1.

\section{Color of the holotype preserved in alcohol $70 \%$}

In preservative (Figs 1-2), dorsal background color of the body, head, and limbs dark brown. All dorsal blotches dark brown, darker than background color. Interorbital blotch triangular-shaped, one vertex over each eyelid, the third vertex connected with the tip of an arrow-shaped blotch medially located on the dorsum of the body. Middle of the arrow-head with a small light spot, posterior portion of the arrow extends transversely towards each inguinal gland. Urostyle region bears a longitudinal blotch with anterior margin poorly defined, centered by a longitudinal light blotch. Some poorly defined and irregularly shaped small blotches scattered through dorsal surfaces of head and body. Inguinal gland ca $90 \%$ covered by a black ocellus. Dorsal surfaces of thigh, tibia, and foot with transversal blotches. Many white dots scattered throughout dorsal surface of body and limbs, mainly outlining the more distinct blotches and the black ocelli over the inguinal gland. Heel, anterior part of knee, and forearm with a black blotch. Upper arm with a longitudinal black blotch covering its posterior surface and the elbow. Dorsolateral black blotches, dorsally outlined by small white dots, extending from the posterior margin of the eye through the supra tympanic fold and reaching the second third of the flank. Elongated black blotches extends from the tip off the snout to the eye, passing over the nostril and canthus rostralis. Irregularly shaped black blotches on the loreal region and upper lip. Region between eyes and the insertion of the arms, pale cream. Ventral surfaces of the limbs brown with scattered light spots; ventrolateral edge of forearm 
with a black blotch over glandular tissue. Black blotch above the cloaca, dorsally outlined by small white spots, curved down toward the back of the thighs. Gular region and chest predominantly pale cream, stained with very small dark dots. Ventral border of mandible brown colored, without distinct blotches. Belly with dark vermiculation pattern on a pale cream background. Iris dark brown with a faintly visible black vermiculation; pupil black and horizontal.

\section{Color in life}

Gular region, chest, axillary region, lower border of anterior half of the flanks, and region between eyes and the insertion of the arms yellow (Fig. 3B-D). Inguinal region pink posteriorly to the black ocelli and yellow around its anterior edge (Fig. 3A, C-D). Ventral surface of limbs pinkish brown (Fig. 3C). Background color of belly pale cream, slightly bluish (Fig. 3C). Overall dorsal background and blotches coloration varying from brownish to greenish, background color with some sparkled areas of cream and orange brown.

\section{Variation}

Measurements and proportions of 13 adult males are presented in Table 1. In life, color of dorsal background of head, body, and limbs may vary from pale yellow to dark brown; some individuals had these areas, as well as the region between eyes and the insertion of the arms, stained by pinkish coloration in different levels of area size and color intensity. Yellow coloration present on gular region, chest, axillary region, lower border of anterior half of the flanks, and the region between eyes and the insertion of the arms may vary in intensity. Ventral surface of thigh may be pinkish. White dots outlining dorsal blotches may vary in size and number, forming distinct lines in some individuals; these white dots/lines may be greenish in live individuals. Few individuals have dorsal pattern weakly distinct in life and in preservative. Dorsal arrow-shaped blotch may present interruptions and be slightly irregularly shaped. Irregularly shaped small blotches scattered across dorsal surfaces of head and body may vary in number, size, shape, position, and distinctness from the background. Background color of belly may be bluish in different intensities. Brown coloration of the ventral border of mandible is more visible in fixed specimens, after the yellow coloration has faded. In fixed specimens it varies from occupying just the edge of the mandible to the anterior half of gular region. Tympanum may be slightly discernible externally in some individuals. Snout may be rounded in lateral view. Dorsum of the head, body, thighs, and tibiae may be slightly rugose. Dark superficial keratinized layer of the nuptial pad may be peeled; however, nuptial pad remains visible.

\section{Advertisement and aggressive call}

We identified two call types, the advertisement and an aggressive call (of undetermined specific function, see Toledo et al. 2015). Both the advertisement ( $\mathrm{n}=386$ calls from seven individuals) and aggressive calls $(\mathrm{n}=43$ calls from four individuals) presented a pulsed structure. They differentiate from each other mainly by the call duration, note rate, and the context in which the recordings were obtained (advertisement calls recorded in the field and aggressive calls recorded from the aqua-terrarium). The advertisement calls had variable number of notes (1-3), frequency, and amplitude of notes varying in the call (Fig. 4; Table 2). These calls seemed to be composed of a harmonic structure, but the harmonics were not clear in most of the calls. The most common advertisement call structure was that with 3 notes (exhibited in $63.63 \%$ of calls, $34.1 \%$ had two notes and $2.27 \%$ had only one note) with the dominant frequency in the second note (48.64\% of the calls, $35.13 \%$ of calls had the dominant frequency in the third note and $16.21 \%$ in the first note). This call was emitted at rate of $0.87-2.04$ calls/ second, lasting between 0.07 to 0.3 seconds, with a dominant frequency of $0.94-2.63 \mathrm{kHz}$ (average of $1.7 \mathrm{kHz} \pm 0.31 \mathrm{SD}$ ). On the other hand, we analyzed 1306 aggressive call notes from four males (Fig. 5; Table 3). These calls were emitted by males close to other calling males, but it was not possible to determine a specific function (e.g., territorial, encounter or fighting calls). Aggressive calls were organized in groups of 9-118 notes, lasting 4.73-53.46 seconds, longer than advertisement calls, and with a dominant frequency of $1.59-2.30 \mathrm{kHz}$. 


\section{Tadpole}

Maximum total length $28.2 \mathrm{~mm}$, at stage 37. Body depressed $(\mathrm{BH} / \mathrm{BW}=0.73-0.85$; Fig. 6A-B, H), 0.39-0.43 times TL; in dorsal view, ovoid with well-marked lateral constrictions at the spiracle level; in lateral view, ventral contour convex in gular and abdominal regions, with a well-defined constriction slightly anterior to the spiracle level. Snout truncated in lateral view and obtuse in dorsal view (BWN/ $\mathrm{BWE}=0.71-0.75)$. Nostrils elliptical, small $(\mathrm{ND} / \mathrm{BL}=0.02-0.02)$, dorsally located, anterodorsally
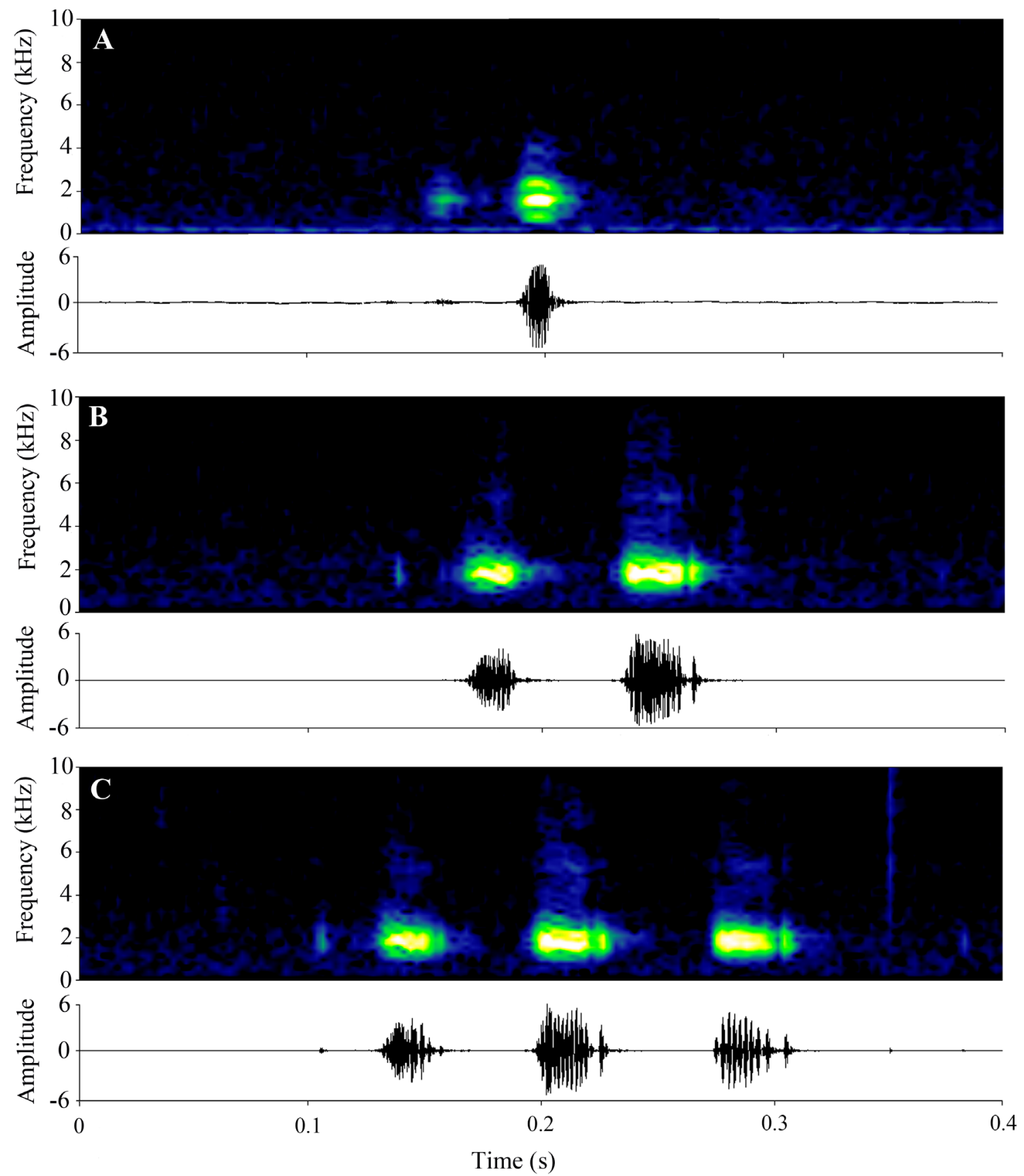

Fig. 4. Spectrograms (above) and oscillograms (below) of advertisement calls of Physalaemus araxa sp. nov., highlighting an increasing complexity with one (A), two (B), or three (C) notes; recorded in the Caparaó National Park, municipality of Ibitirama, state of Espírito Santo, Brazil. 
Table 2. Temporal and spectral parameters of the advertisement call of Physalaemus araxa sp. nov. and P. maculiventris (Lutz, 1925). Values are presented as a range (average $\pm \mathrm{SD}$ ); $\mathrm{n}=$ number of males (number of calls analyzed).

\begin{tabular}{|c|c|c|c|c|}
\hline \multirow[b]{2}{*}{ Call parameters } & \multirow{2}{*}{$\begin{array}{c}\text { Physalaemus } \\
\text { araxa sp. nov. } \\
\text { Ibitirama, } \\
\text { ES }\end{array}$} & \multicolumn{3}{|c|}{ Physalaemus maculiventris } \\
\hline & & $\begin{array}{l}\text { Salesópolis, } \\
\text { SP }\end{array}$ & $\begin{array}{c}\text { Paranapiacaba, } \\
\text { SP }\end{array}$ & $\begin{array}{c}\text { São Paulo (Zoo), } \\
\text { SP }\end{array}$ \\
\hline Variables & $\mathrm{n}=7(386)$ & $\mathrm{n}=1(11)$ & $\mathrm{n}=1(98)$ & $\mathrm{n}=1(52)$ \\
\hline Call duration (s) & $\begin{array}{c}0.07-0.3 \\
(0.13 \pm 0.03)\end{array}$ & $\begin{array}{c}0.20-0.23 \\
(0.22 \pm 0.01)\end{array}$ & $\begin{array}{c}0.09-0.63 \\
(0.22 \pm 0.08)\end{array}$ & $\begin{array}{c}0.14-0.74 \\
(0.30 \pm 0.14)\end{array}$ \\
\hline Note duration (s) & $\begin{array}{c}0.01-0.2 \\
(0.03 \pm 0.02)\end{array}$ & - & - & - \\
\hline Intercall interval (s) & $\begin{array}{c}0.09-3.24 \\
(0.54 \pm 0.38)\end{array}$ & $\begin{array}{c}0.90-3.61 \\
(1.66 \pm 0.80)\end{array}$ & $\begin{array}{c}0.01-2.11 \\
(0.48 \pm 0.37)\end{array}$ & $\begin{array}{c}0.32-2.33 \\
(0.86 \pm 0.58)\end{array}$ \\
\hline Internote interval (s) & $\begin{array}{c}0.02-0.16 \\
(0.03 \pm 0.02)\end{array}$ & - & - & - \\
\hline Call rate (calls/s) & $\begin{array}{c}0.87-2.04 \\
(1.32 \pm 0.37)\end{array}$ & 0.58 & 1.11 & 0.53 \\
\hline Number of notes per call & $\begin{array}{c}1-3 \\
(2.60 \pm 0.54)\end{array}$ & $1.00 \pm 0$ & $1.00 \pm 0$ & $1.00 \pm 0$ \\
\hline Dominant frequency $(\mathrm{kHz})$ & $\begin{array}{c}0.94-2.63 \\
(1.70 \pm 0.31)\end{array}$ & $\begin{array}{c}1.26-1.26 \\
(1.26 \pm 0.00)\end{array}$ & $\begin{array}{c}0.94-2.25 \\
(1.11 \pm 0.13)\end{array}$ & $\begin{array}{c}1.31-1.88 \\
(1.49 \pm 0.13)\end{array}$ \\
\hline Minimum frequency $(\mathrm{kHz})$ & $\begin{array}{c}0.19-1.69 \\
(0.93 \pm 0.32)\end{array}$ & $\begin{array}{c}0.86-0.95 \\
(0.94 \pm 0.03)\end{array}$ & $\begin{array}{c}0.75-1.50 \\
(0.76 \pm 0.07)\end{array}$ & $\begin{array}{c}1.13-1.31 \\
(1.13 \pm 0.04)\end{array}$ \\
\hline Maximum frequency (kHz) & $\begin{array}{c}1.88-39.56 \\
(2.82 \pm 4.06)\end{array}$ & $\begin{array}{c}1.72-1.72 \\
(1.72 \pm 0.00)\end{array}$ & $\begin{array}{c}1.50-5.06 \\
(2.22 \pm 0.86)\end{array}$ & $\begin{array}{c}1.69-2.25 \\
(2.06 \pm 0.2)\end{array}$ \\
\hline Frequency bandwidth (kHz) & $\begin{array}{c}0.56-39.19 \\
(1.88 \pm 4.14)\end{array}$ & $\begin{array}{c}0.77-0.86 \\
(0.78 \pm 0.03)\end{array}$ & $\begin{array}{c}0.75-4.31 \\
(1.45 \pm 0.84)\end{array}$ & $\begin{array}{c}0.56-1.13 \\
(0.92 \pm 0.19)\end{array}$ \\
\hline
\end{tabular}

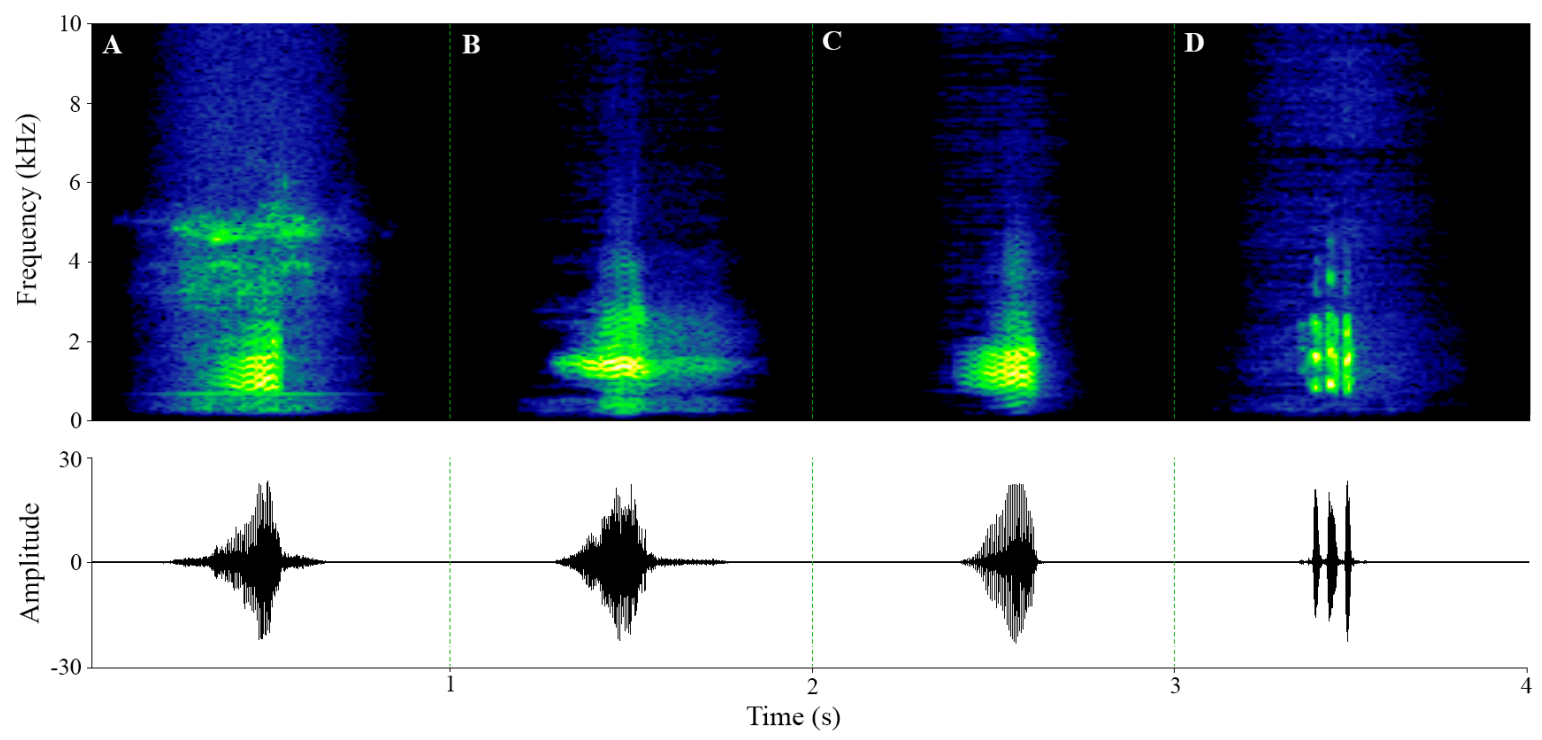

Fig. 5. Spectrogram (above) and oscillogram (below) of advertisement calls. A-C. Three populations of Physalaemus maculiventris (Lutz, 1925). A. Paranapiacaba (FNJV 31815). B. São Paulo (FNJV 31988). C. Salesópolis (FNJV 33756). - D. P. araxa sp. nov. from Ibitirama (FNJV 34633). 
Table 3. Temporal and spectral parameters of the aggressive call from four males of Physalaemus araxa sp. nov. Values are presented as a range (average $\pm \mathrm{SD}$ ).

\begin{tabular}{lc}
\hline Call parameters & Physalaemus araxa sp. nov. \\
\hline Call duration (s) & $4.73-53.46(18.99 \pm 11.58)$ \\
Note duration (s) & $0.04-0.58(0.16 \pm 0.05)$ \\
Intercall interval (s) & $0.57-603.83(151.62 \pm 187.92)$ \\
Internote interval (s) & $0.11-604.39(4.79 \pm 40.95)$ \\
Number of notes per call & $9.00-118.00(36.77 \pm 27.33)$ \\
Dominant frequency $(\mathbf{k H z})$ & $1.59-2.30(2.04 \pm 0.22)$ \\
Minimum frequency $(\mathbf{k H z})$ & $1.45-1.82(1.62 \pm 0.14)$ \\
Maximum frequency $(\mathbf{k H z})$ & $2.30-3.00(2.60 \pm 0.22)$ \\
\hline
\end{tabular}

directed, slightly closer to the tip of snout than to the eyes (NSD/ESD $=0.38-0.44)$; presence of a continuous and elevated marginal rim, with a small fleshy projection on the medial portion (Fig. 6E). Eyes dorsally located (IOD/BWE $=0.55-0.64)$, dorsolaterally directed, $0.20-0.25$ times BWE. Spiracle sinistral, lateral, visible in dorsal and ventral views $(\mathrm{SVD} / \mathrm{BH}=0.47-0.60)$, posterodorsally directed, short (SL/BL $=0.08-0.10)$, opening at the middle third of the body $(\mathrm{SSD} / \mathrm{BL}=0.55-0.58)$; inner wall fused to the body, with its distal portion as a slight ridge (Fig. 6F). Vent tube dextral, posteriorly directed, short (VTL/BL $=0.07-0.10)$, with a large opening, fused to the ventral fin, and positioned at its ventral margin (Fig. 6G). Tail moderately high, with about the same height as the body ( $\mathrm{MTH} / \mathrm{BH}=0.95-1.00$ ); tail musculature slender $(\mathrm{TMH} / \mathrm{BH}=0.29-0.39)$, straight, not reaching the broadly rounded tip of tail. Dorsal and ventral fins about the same height $(\mathrm{DFH} / \mathrm{TAL}=0.11-0.14$; VFH/TAL $=0.11-0.14)$, with the external margins slightly convex. Dorsal fin emerging on the posterior third of the body at a moderate sloping $\left(\mathrm{DFIA}=15-17^{\circ}\right)$; maximum height at the middle third of the tail. Oral disc medium-sized (ODW/ $\mathrm{BW}=0.31-0.35$, measured with oral disc closed), anteroventrally positioned (ODP $=33-43^{\circ}$ ), laterally emarginated (Fig. 6D); single row of conical and alternate marginal papillae interrupted anteriorly by a wide anterior gap (AGL/ODW $=0.58-0.60)$; few (3-4) small submarginal papillae arranged in a small row at the supra-angular region and other (1-3) aligned at the fold of the oral disc emargination. Labial tooth row formula (LTRF) 2(2)/3(1); A2, frequently irregular at the lateral portions, longer than A1, which is irregular along its length; P1 and P2 equal in length, slightly longer than P3; jaw sheaths wide, finely serrated on the margins (about 36 serrations on the upper sheath), upper jaw sheath M-shaped and lower jaw sheath V-shaped. Stitches of lateral line system not distinct; nerves of the ventral body-line and longitudinal oral line evident laterally, and nerves of dorsal and middle lines in the posterior portion of body. Intestinal tube circularly coiled (Fig. 6C), switchback point slightly dislocated from the center of the abdominal region. Measurements are shown in Table 4.

\section{Tadpole coloration}

In preservative, body densely covered by dark brown melanophores, except the gular region, which is pale (Fig. 6A-C); intestine tube barely visible, almost covered by melanophores; rectus abdominis visible from the region of posterior limbs to the peribranchial region; distal portion of spiracle not pigmented. Tail musculature cream, homogeneously pigmented by melanophores; fins translucent, finely reticulated with filiform melanophores mainly the dorsal fin.

In life, body dark brown, finely speckled with iridophores (Fig. 6H); spiracle translucent; venter cream in the gular and abdominal regions; iris black with golden dots scattered and a narrow golden rim surrounding the pupil. Tail musculature cream, homogeneously covered with melanophores except by few small, depigmented areas; fins translucent, finely reticulated with filiform melanophores and golden dots; dorsal fin more pigmented than ventral fin. 
Table 4. Measurements (in $\mathrm{mm}$ ) and angles of tadpoles of Physalaemus araxa sp. nov. ( $\mathrm{n}=9$; ZUECAMP 24214) for the stages 37-38 (Gosner 1960). Data are presented as range (mean \pm SD). See Material and methods for abbreviations.

\begin{tabular}{lc}
\hline Measurement & Physalaemus araxa sp. nov. \\
\hline TL & $25.2-28.2(26.9 \pm 1.1)$ \\
BL & $10.6-11.5(11.1 \pm 0.4)$ \\
TAL & $14.6-16.9(15.8 \pm 0.8)$ \\
MTH & $5.2-6.1(5.7 \pm 0.3)$ \\
DFH & $1.7-2.2(2 \pm 0.2)$ \\
VFH & $1.8-2.2(2 \pm 0.2)$ \\
TMH & $1.7-2.2(1.9 \pm 0.2)$ \\
BH & $5.5-6.1(5.8 \pm 0.3)$ \\
SL & $1-1.1(1 \pm 0.1)$ \\
SVD & $2.7-3.3(3 \pm 0.3)$ \\
SSD & $6-6.6(6.3 \pm 0.3)$ \\
ED & $1.1-1.4(1.2 \pm 0.1)$ \\
BW & $7.2-7.6(7.4 \pm 0.2)$ \\
BWN & $3.3-3.8(3.6 \pm 0.2)$ \\
BWE & $5-5.8(5.4 \pm 0.3)$ \\
TMW & $1.4-1.9(1.7 \pm 0.2)$ \\
END & $1.7-1.8(1.8 \pm 0.1)$ \\
ESD & $2.7-3.1(2.9 \pm 0.2)$ \\
NSD & $1.1-1.4(1.2 \pm 0.1)$ \\
ND & $0.2-0.3(0.2 \pm 0)$ \\
IND & $1.1-1.2(1.2 \pm 0)$ \\
IOD & $3.1-3.4(3.2 \pm 0.1)$ \\
ODW & $2.3-2.6(2.4 \pm 0.1)$ \\
ODP & $30-43.3(34.4 \pm 4.7)$ \\
AGL & $1.4-1.5(1.5 \pm 0)$ \\
DFIA & $15-17(16.2 \pm 1)$ \\
VTL & $0.8-1.4(1.1 \pm 0.2)$ \\
\hline
\end{tabular}

\section{Karyotype}

The diploid chromosomal complement of $P$. araxa sp. nov. is composed of 22 chromosomes, with 8 pairs of metacentric chromosomes $(1,2,5,6,7,8,9$, and 10; pairs 2 and 7 are at the threshold between metacentric and submetacentric classification), 2 pairs of submetacentric chromosomes (3 and 4), and a telocentric chromosome pair (11) (Fig. 7; Table 5). Large amounts of C-banded constitutive heterochromatin were detected in the centromeric region of all chromosomes. Faint C-bands were also observed interstitially on the long arm of chromosome 3 in some metaphases (inset in Fig. 7B).

\section{Phylogenetic inferences and genetic distances}

In both MrBayes and TNT analyses, the new species, together with Physalaemus cf. araxa from Santa Teresa, ES, composed a highly supported clade that was the sister group of $P$. maculiventris in the Physalaemus signifer clade (Fig. 8). Two genetic lineages were recognized in the P. maculiventris clade, one represented by the specimens from Bananal, SP, and another by specimens from three other localities (Fig. 8). High genetic distances were found between these P. maculiventris lineages and also between each of them and the new species (Table 6). In contrast, the $p$-distances estimated from the 16Sar-16Sbr and $\mathrm{H} 1$ fragments, between the specimen from Santa Teresa and the new species, were low, 1.48 and 2.57 , respectively (Table 6). 


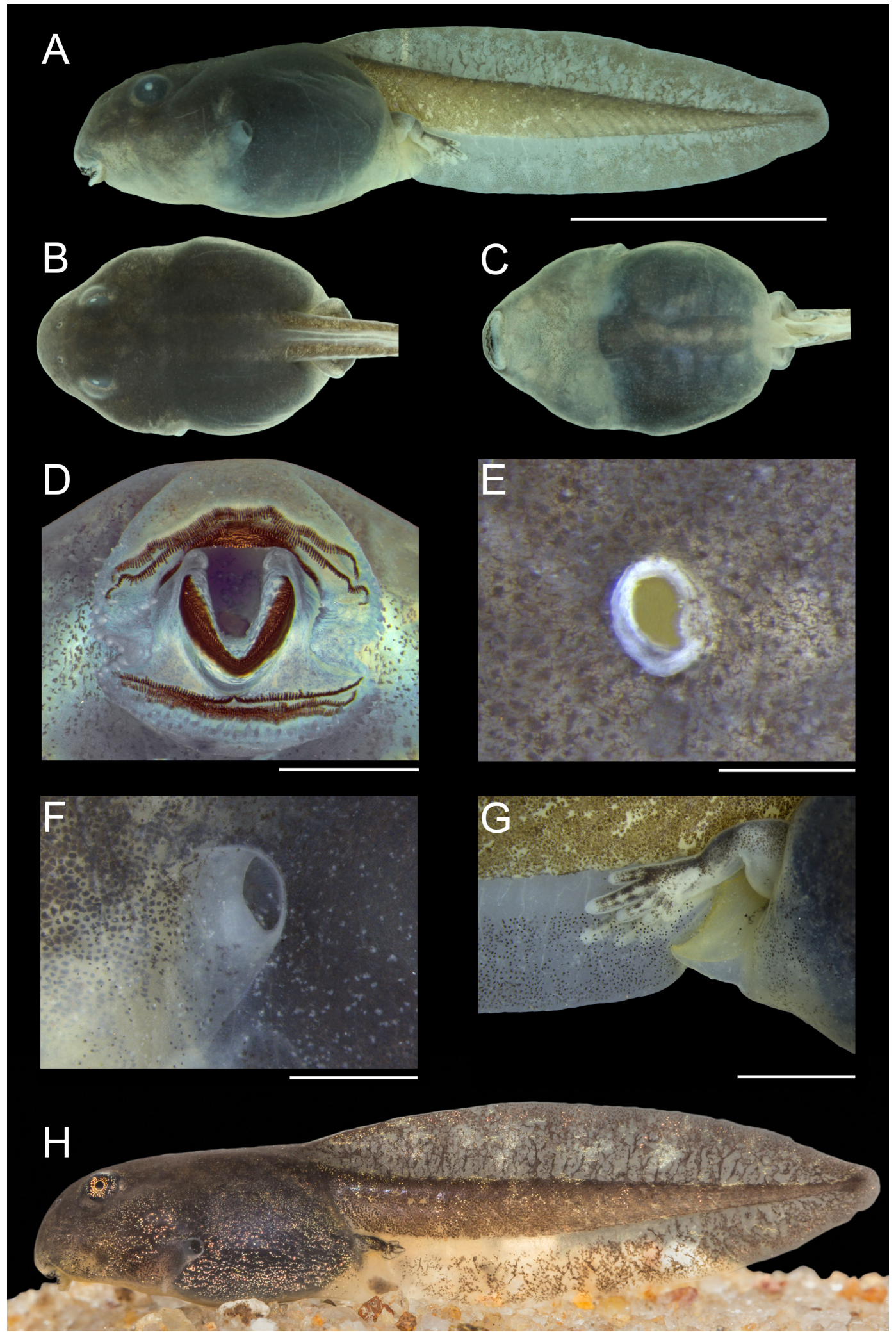

Fig. 6. Tadpole of Physalaemus araxa sp. nov. at stage 37 (ZUEC-AMP 24214). A. Lateral view. B. Dorsal view. C. Ventral view. D. Oral disc completely opened. E. Details of the right nostril in frontal view. F. Spiracle in lateral view. G. Vent tube in lateral view. H. Tadpole of Physalaemus araxa sp. nov. in life (photo not to scale). Scale bars: A-C, F-G $=10 \mathrm{~mm} ; \mathrm{D}=1 \mathrm{~mm} ; \mathrm{E}=0.5 \mathrm{~mm}$. 
Table 5. Morphometric parameters of the chromosomes of Physalaemus araxa sp. nov.; chromosomal classification according to their centromeric position followed Green \& Sessions (1991). Abbreviations: $\mathrm{AR}=$ arm ratio; $\mathrm{RL}=$ relative length; $\mathrm{CC}=$ centromeric classification: $\mathrm{M}=$ metacentric; $\mathrm{SM}=$ submetacentric; $\mathrm{T}=$ telocentric. Asterisks represent the pairs at the threshold between metacentric and submetacentric classification.

\begin{tabular}{cccccccccccc}
\hline & \multicolumn{1}{c}{ Chromosome pair } \\
& $\mathbf{1}$ & $\mathbf{2}$ & $\mathbf{3}$ & $\mathbf{4}$ & $\mathbf{5}$ & $\mathbf{6}$ & $\mathbf{7}$ & $\mathbf{8}$ & $\mathbf{9}$ & $\mathbf{1 0}$ & $\mathbf{1 1}$ \\
\hline RL & 0.141 & 0.124 & 0.114 & 0.105 & 0.105 & 0.097 & 0.093 & 0.069 & 0.066 & 0.056 & 0.033 \\
AR & 1.269 & 1.667 & 2.089 & 2.097 & 1.488 & 1.348 & 1.641 & 1.307 & 1.444 & 1.376 & - \\
CC & $\mathrm{M}$ & $\mathrm{M}^{*}$ & $\mathrm{SM}$ & $\mathrm{SM}$ & $\mathrm{M}$ & $\mathrm{M}$ & $\mathrm{M}$ & $\mathrm{M}$ & $\mathrm{M}$ & $\mathrm{M}$ & $\mathrm{T}$ \\
\hline
\end{tabular}

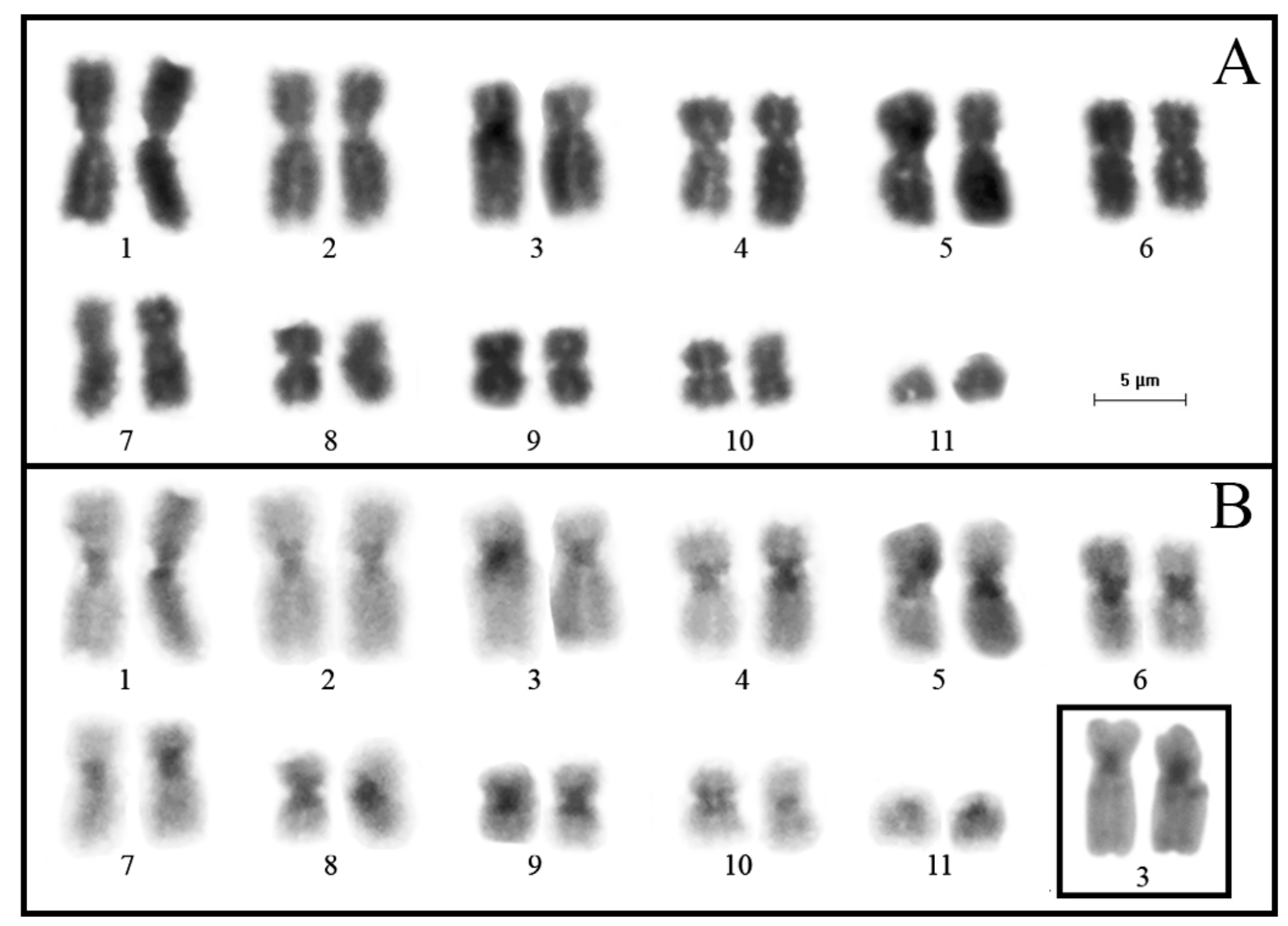

Fig. 7. Karyotype of Physalaemus araxa sp. nov. A. Giemsa-stained. B. C-banded. The insert in B shows the faint C-band on chromosome pair 3. 
Table 6. Uncorrected $p$-distances (\%) between Physalaemus araxa sp. nov., P. maculiventris, and Physalaemus cf. araxa from Santa Teresa, ES. In the lower triangle, values estimated from H1 fragments; in the upper triangle, values inferred from the 16Sar-16Sbr fragment of the 16S rRNA gene (540 bp). Diagonal line presents uncorrected $p$-distances identified within each species or lineage, based on the H1 (left) and 16Sar-16Sbr (right) fragments. En-dash denotes that only one sequence is available.

\begin{tabular}{lcccc}
\hline & $\mathbf{1}$ & $\mathbf{2}$ & $\mathbf{3}$ & $\mathbf{4}$ \\
\hline 1. Physalaemus araxa sp. nov. & $-/-$ & 1.48 & 5.83 & 5.20 \\
2. Physalaemus cf. araxa - Santa Teresa & 2.57 & $-/-$ & 6.94 & 6.12 \\
3. P. maculiventris (topotype included) & 5.89 & 6.26 & $2.0 / 2.0$ & 3.72 \\
4. P. maculiventris - Bananal & 6.39 & 6.59 & 3.31 & $0.4 / 0$ \\
\hline
\end{tabular}

\section{Remarks}

The phylogenies presented in Lourenço et al. (2015) and in Leal et al. (2020) have a terminal named "P. signifer (Congonhas do Campo, MG)". The city name "Congonhas do Campo" was incorrectly used as it has changed to "Congonhas" since 1948. Herein we fixed it, changing the terminal name to "P. signifer (Congonhas, MG)" to avoid any misunderstandings regarding the city name.

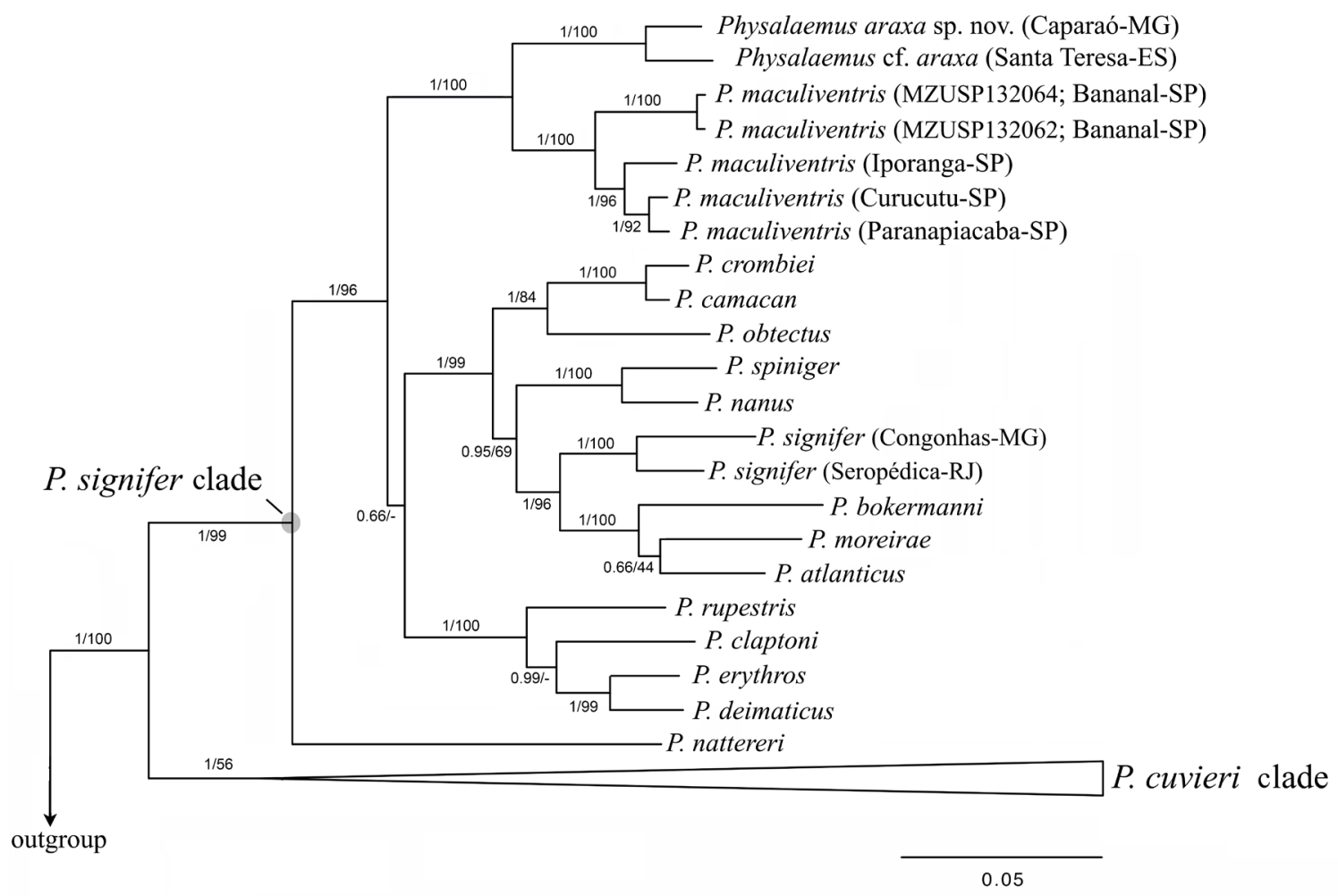

Fig. 8. Interspecific phylogenetic relationships of Physalaemus araxa sp. nov. inferred from $12 \mathrm{~S}$ rRNA, tRNA-val, and 16S rRNA mitochondrial genes (H1 fragment sequences) by MrBayes and TNT. Numbers indicate posterior probabilities (left) or bootstrap values (right) in the MrBayes and TNT analyses, respectively. Hyphens indicate nodes that were not recovered in the TNT analysis. 


\section{Natural history}

Individuals of Physalaemus araxa sp. nov. reproduce aggregated in shallow temporary swampy ponds (Fig. 9) in altitudinal grasslands (campo de altitude) with interspersed granitic outcrops, a typical phytophysiognomy of the highlands of the Mantiqueira mountain range (Safford 2007; Vasconcelos 2010). Individuals were registered between $2551 \mathrm{~m}$ a.s.1 (Lagoa da Sombra) and $2656 \mathrm{~m}$ a.s.1. (Três Lagoas), P. araxa sp. nov. was the only anuran species found breeding at those high-altitude ponds (observation also corroborated by the autonomous recordings). After amplexus, pairs produced floating foam nests where eggs were laid. Two foam nests were collected on 5 October 2017. Ten days after, tadpoles started leaving the nests and at 12 November tadpoles reached the stage 25. We counted 187 tadpoles from those nests. Benthic exotrophic tadpoles (ecomorphological guild II: A:1 sensu Altig \& McDiarmid 1999) were observed in the wild in October and December 2017. Calling activity, foam nests, and tadpoles were registered between October 2017 and December 2017. Immediately metamorphosed froglets (with no evidence of tail), raised in captivity, had between 7.76 and $8.85 \mathrm{~mm}$ (ZUEC-AMP 24403-5).

Males were found calling from the ground or on top of peat moss (Sphagnum sp.) hidden on the pond's margins. During the complete day ( $24 \mathrm{~h}$ ) that we recorded P. araxa sp. nov. vocal activity (Fig. 10), males called during all $24 \mathrm{~h}$, however, clearly presenting predominant nocturnal calling activity. Most of the calls were recorded from 18:00 to 3:00, reaching the peak of calling activity between 19:00 and 21:00.

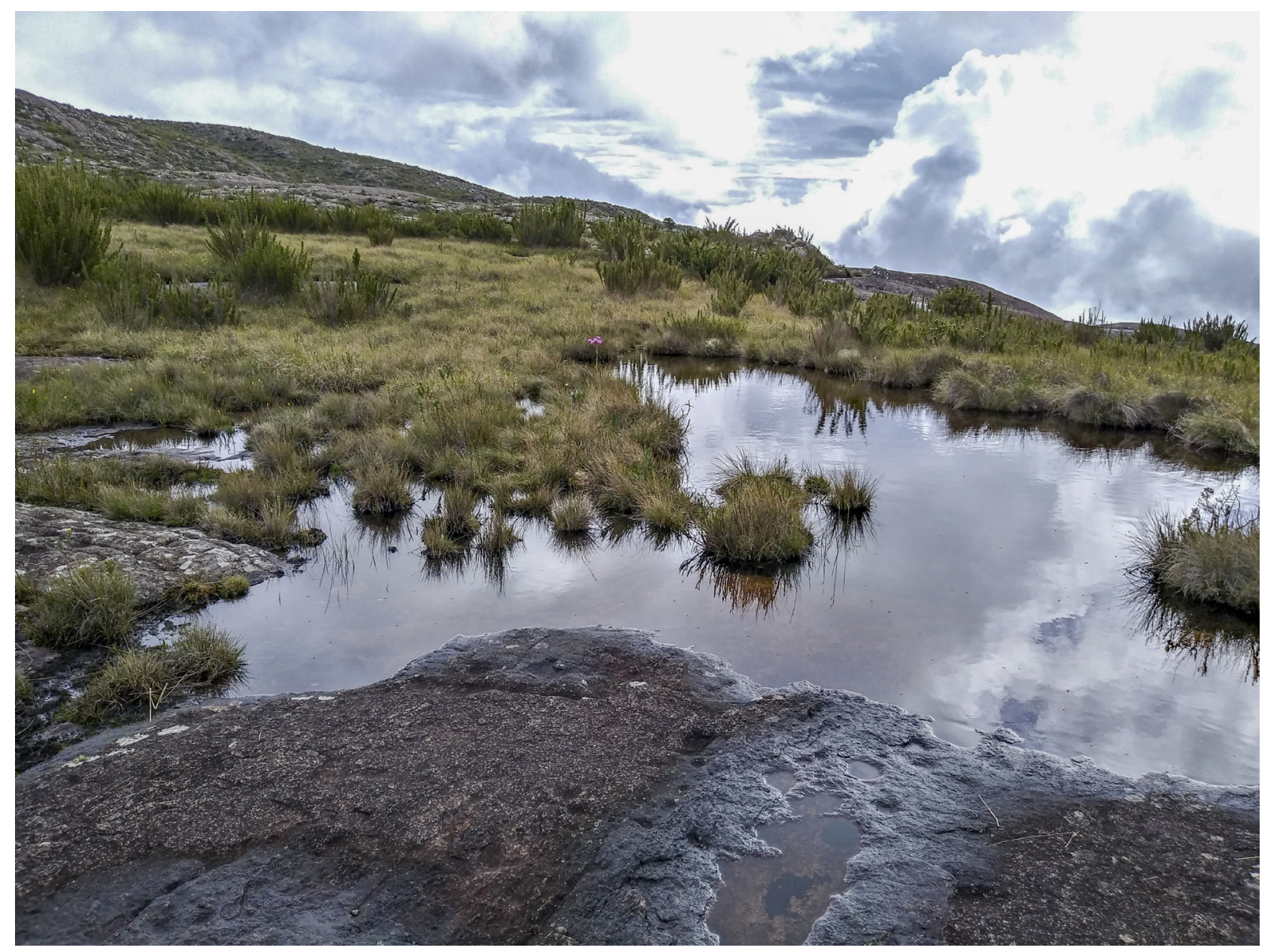

Fig. 9. Type locality of Physalaemus araxa sp. nov., Lagoa da Sombra, at Parque Nacional do Caparaó. 


\section{Discussion}

\section{External morphology, phylogenetic inferences, and genetic distances}

The ability of Physalaemus araxa sp. nov. to inhabit areas restricted to such high altitudes (2551-2656 $m$ a.s.1.) in a harsh environment prone to constant frosts, is not its only highly distinctive characteristic. The new species' gular region and chest predominantly yellow colored in live individuals is also a novelty in Physalaemus, distinguishing it from all congeners, which have the gular region predominantly dark. During field work we observed some males of $P$. araxa sp. nov. adopting an upright posture with vocal sac slightly inflated, displaying its conspicuous yellow color (Fig. 3B-C). This type of behavior has already been identified as related to intraspecific communication in anurans, with the yellow coloration of the vocal sac contrasting with the background, enhancing the location of the individual (Hödl \& Amézquita 2001; Hartmann et al. 2005). Rosenthal et al. (2004) demonstrated that for Engystomops pustulosus (Cope, 1864), the vocal sac expansion during calling activity plays an important role in the species' communication as females preferred calls accompanied by vocal sac inflation over those with no inflation, even though E. pustulosus does not have throat bearing bright colors. Thus, it is possible

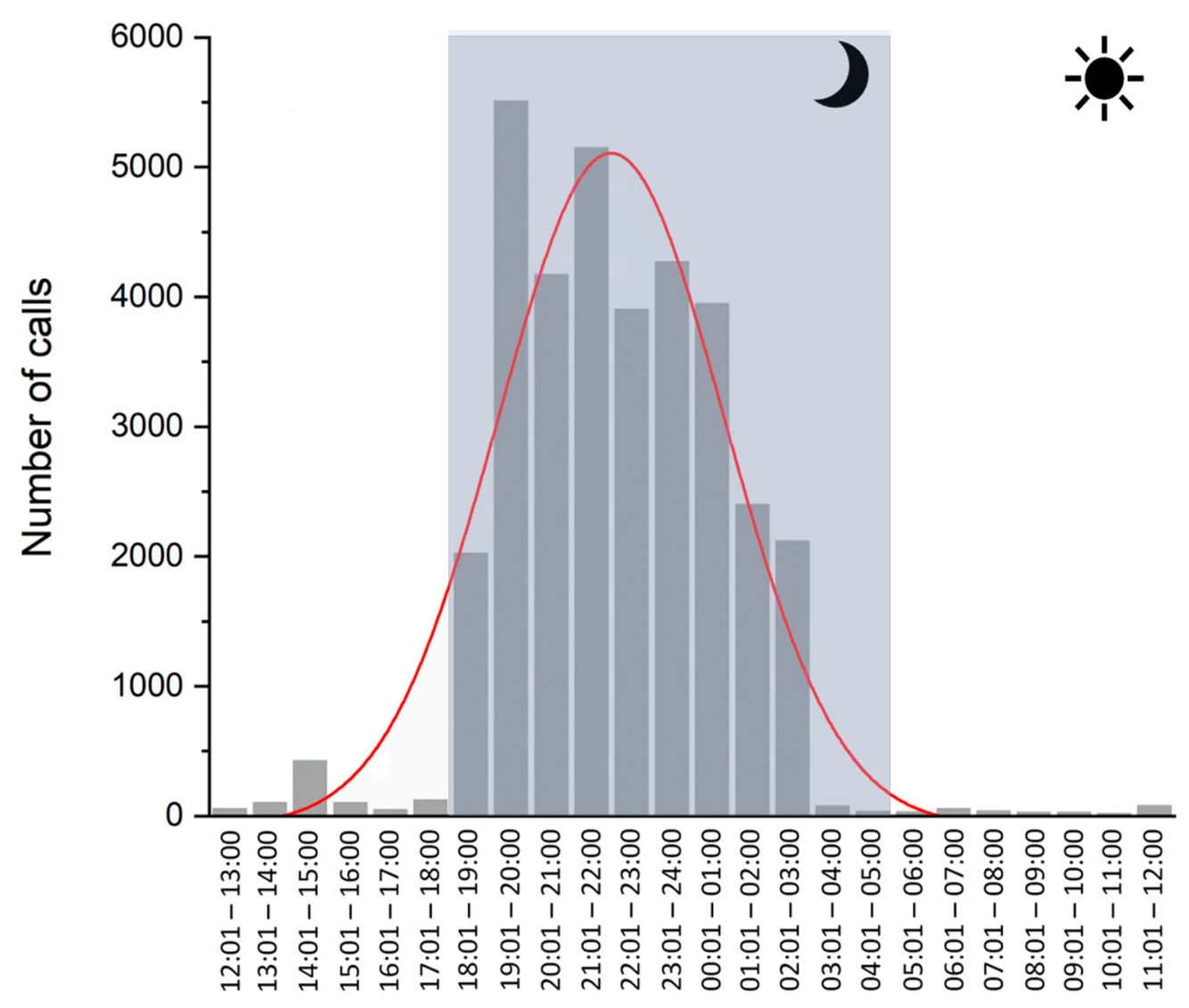

Fig. 10. Physalaemus araxa sp. nov. males calling activity per hour along one complete day in the top of the Caparaó National Park, municipality of Ibitirama, state of Espírito Santo, Brazil. The shaded blue indicates nocturnal period and the red line indicates the normal Gaussian fitted curve for the calling activity (adjusted after running the normality test). 
that for $P$. araxa sp. nov. the combination of a bright yellow throat and expansion of the vocal sac during calling activity promotes even better signs for visual communication.

Physalaemus araxa sp. nov. was recovered in our phylogenetic inference fully supported as sister to a specimen collected at Santa Teresa, ES (Fig. 8). This sample from Santa Teresa was already included in the phylogenies presented by Lourenço et al. (2015) and Leal et al. (2020), where it was identified as P. maculiventris and recovered as sister to specimens of P. maculiventris from the municipality of Bananal, SP. Besides the phylogenetic proximity, the values of genetic distance acquired from the 16S rRNA gene between the new species and the sample from Santa Teresa were surprisingly low, set at $1.48 \%$, much lower than the 3\% suggested by Fouquet et al. (2007) and Lyra et al. (2017) as a threshold for intraspecific variation. This value is also significantly lower than the values found between other species of Physalaemus, such as the ones from the P. deimaticus species group (Leal et al. 2020). These data indicate that the sample from Santa Teresa could be from an individual belonging to the new species, instead of being a $P$. maculiventris as previously thought. We have tried to find the voucher specimen for making a morphological evaluation, but we were unsuccessful in finding it. The tissue sample was obtained from the Célio F.B. Haddad Amphibian Collection but there was no information regarding the specimen collector or the location of the voucher individual. We even contacted the herpetologist J.L. Gasparini who worked at Santa Teresa but this did not help to either find the voucher specimen or any information about this specific specimen. Although we could not find the voucher specimen from the tissue sample, we analyzed seven specimens from Santa Teresa that had previously been identified as $P$. maculiventris. Despite being from a location $740 \mathrm{~km}$ in a straight line far from the species type locality (Paranapiacaba, SP), those seven specimens proved to be morphologically indistinguishable from topotypes of $P$. maculiventris, sharing its singular characteristics of a pointed snout, dark throat, and black bold blotches over the belly, thus, conspicuously distinct from $P$. araxa sp. nov. Therefore, we decided to designate the specimen from Santa Teresa, sister to Physalaemus araxa sp. nov., as Physalaemus cf. araxa. Additionally, it is noteworthy that the environment occupied by $P$. araxa sp. nov. at its type locality is singular and does not match any environment found in Santa Teresa, including its altitudinal range of occurrence. Considering all these uncertainties regarding this occurrence record of Physalaemus $\mathrm{cf}$. araxa, it is even possible that the collecting locality attributed to it is wrong. Thus, until a more reliable record of the new species is made for areas outside the type locality, we consider the species as restricted to the sites where the type series was collected.

We added three new samples of Physalaemus maculiventris to the molecular data matrix previously used by Lourenço et al. (2015) and Leal et al. (2020), one from a topotype specimen (Paranapiacaba, SP) and the others from Curucutu, SP ( $\sim 40 \mathrm{~km}$ southwest of the type locality), and Iporanga, SP ( $240 \mathrm{~km}$ southwest of the type locality) (Supp. file 2). These three specimens formed a fully supported clade, sister to a clade composed of two individuals of $P$. maculiventris from Bananal, SP. The genetic distance of the $16 \mathrm{~S}$ gene fragment was low among the specimens from the type locality (Paranapiacaba), Curucutu, and Iporanga ( $p$-distance of $2 \%$ ). On the other hand, the $p$-distance between these three specimens and the two specimens from Bananal was relatively high ( $p$-distance of $3.72 \%$ ). This relatively high value may indicate the existence of undescribed species within P. maculiventris and should be further investigated, especially considering the fact that we could not access the voucher specimens from Bananal nor recordings from this locality. We have examined adult specimens of $P$. maculiventris from many localities (see Appendix I for a complete list), from São Bento do Sul (Santa Catarina) to Santa Teresa (ES) and, even though it covered approximately $1150 \mathrm{~km}^{2}$ of distribution range, we could not find morphological characters that could be used as diagnosis to any of the analyzed populations. However, with such a wide distribution range and very few registers made, always all along the mountains of the Brazilian coastal area, this species seems also to be a good model for phylogeographic and biogeographic studies. 


\section{Bioacoustics and natural history}

The advertisement call of Physalaemus araxa sp. nov. can be distinguished from that of populations of $P$. maculiventris by the higher note rate (number of notes per call), which is commonly three notes in calls of $P$. araxa sp. nov., while $P$. maculiventris presented only one note, as also reported by Hepp \& Pombal (2020). Even with more notes, the advertisement call of $P$. araxa sp. nov. was still shorter than that of $P$. maculiventris. Additionally, aggressive calls were longer than advertisement calls and present a higher note rate, as observed in other species that have these two types of calls ( $P$. maculiventris, $P$. erythros, P. signifer, and P. spiniger; Hepp \& Pombal 2020).

Males of Physalaemus araxa sp. nov. could be found hidden in the border vegetation of the ponds; therefore, the calls we analyzed based on the recordings of the autonomous recorder are likely to be emitted from different individuals. In spite of that, data presented showed to be an adequate temporal proxy for the species activity.

\section{Tadpole}

Fourteen of the 18 species of the P. signifer clade had their tadpoles characterized in the literature (Rugeri \& Weber 2012; Ceron \& Santana 2017; Leal et al. 2020). The tadpoles of Physalaemus araxa sp. nov. differ from the other species of the clade by a combination of characters states of body (i.e., relative body size), vent tube (i.e., vent opening position), tail (i.e., shape of the tail tip), fins (i.e., dorsal and ventral height), and oral disc (i.e., relative size of anterior rows and submarginal papillae configuration). Worth to note that the tadpoles of $P$. araxa sp. nov. are quite distinct from the one of P. maculiventris described and illustrated by Bokermann (1963). Physalaemus araxa sp. nov. has a proportionally larger body than $P$. maculiventris (i.e., $\mathrm{BL} / \mathrm{TL}=0.39-0.43$ in $P$. araxa sp. nov.; 0.33 in P. maculiventris), lacking the well-defined cutaneous fold in the body-tail junction, which is distinct in P. maculiventris (see Bokermann 1963: fig. 2). The gular region contour is also distinct between these species, being convex in P. araxa sp. nov., while it is straight in P. maculiventris. Moreover, in P. araxa sp. nov. the tail has the same height as the body and a broad rounded tip (tail higher that the body and with pointed tip in P. maculiventris; Bokermann 1963). The submarginal papillae arranged in small rows and the A2 tooth row conspicuously longer than A1 also differ P. araxa sp. nov. from P. maculiventris.

\section{Karyotype}

The diploid chromosomal number of Physalaemus araxa sp. nov. $(2 n=22)$ corresponds to that of other species of Physalaemus already karyotyped (Brum-Zorrilla \& Saez 1968; De Lucca et al. 1974; Amaral et al. 2000; Silva et al. 2000; Quinderé et al. 2009; Tomatis et al. 2009; Milani et al. 2011; Provete et al. 2012; Vittorazzi et al. 2014, 2016; Ferro et al. unpublished data), including species of the $P$. signifer clade (i.e., P. atlanticus, $P$. crombiei, . deimaticus, P. moreirae, P. nattereri, P. spiniger, and P. signifer (Beçak 1968; De Lucca et al. 1974; Silva et al. 2000; Lourenço et al. 2006; Ananias et al. 2007; Lourenço et al. 2015)). Physalaemus araxa sp. nov. has a telocentric chromosome pair 11, which may be a synapomorphy of this clade, as previously argued by Lourenço et al. (2015) and Ferro et al. (unpublished data).

\section{Conservation}

This is another example of micro-endemic anuran species, restricted to a mountaintop. Both the extent of occurrence and area of occupancy, as defined by IUCN guidelines (IUCN 2019), are less than $10 \mathrm{~km}^{2}$. That fact, allied to constant natural frosts and occasional anthropogenic fires at the Caparaó National Park (Zornosa-Torres et al. 2020), may constitute a threat to P. araxa sp. nov. Therefore, this species could be classified as endangered, under the category Vulnerable (VU), with the criterion D2, i.e., which is related to a species with a very restricted distribution and immediacy of threat. Besides the formal conservation assessment to this species, made by the Brazilian government or the IUCN, we indicate the long-term monitoring of the species and a practical fire control specifically at the Caparaó National Park top regions. 


\section{Acknowledgments}

We thank C.H. Nunes-de-Almeida, R. Santos, and S. Guedes for helping during fieldwork; J.V. Lacerda for helping checking and photographing specimens housed at Coleção Zoológica do Museu de Biologia Professor Mello Leitão, Santa Teresa, ES; J.L. Gasparini for his valuable help in trying to find the voucher of the sequenced specimen from Santa Teresa, ES; W. Costa for helping with initial molecular analyses; Caparaó National Park and Instituto Chico Mendes de Conservação da Biodiversidade (ICMBio), for the granted access to the park, development, and logistic support for the research (SISBio \#58836-1); The São Paulo Research Foundation (FAPESP \#2011/09239-0; \#2016/25358-3; \#2019/03170-0; \#2019/18335-5); the National Council for Scientific and Technological Development (CNPq\#300896/2016-6); the Brazilian Federal Agency for Support and Evaluation of Graduate Education (CAPES \#001); TLP acknowledges CAPES for his PNPD fellowship (\#88887.468027/2019-00); PCAG thanks the productivity grant provided by the Conselho Nacional de Desenvolvimento Científico e Tecnológico (CNPq \#310301/2018-1).

\section{References}

Altig R. \& McDiarmid R.W. 1999. Tadpoles: The Biology of Anuran Larvae. The University of Chicago Press, Chicago.

Alvarenga M.A., Bezerra da Silva J.E. \& Nunes P.S. 1997. Unidades de relevo. In: IBGE—Instituto Brasileiro de Geografia e Estatística, Recursos Naturais e Meio Ambiente: uma visão do Brasil, $2^{\text {nd }}$ Ed.: 51-73. IBGE—Departamento de Recursos Naturais e Estudos Ambientais, Rio de Janeiro, Brazil.

Amaral J.L.V., Cardoso A.J. \& Recco-Pimentel S.M. 2000. Cytogenetic analysis of three Physalaemus species (Amphibia, Anura). Caryologia 53: 283-288. https://doi.org/10.1080/00087114.2000.10589207

Ananias F., Bombeiro A.L., Silva C.D.B., Silva A.P.Z., Haddad C.F.B. \& Kasahara S. 2007. Cytogenetics of Eupemphix nattereri Steindachner, 1863 (Anura: Leiuperidae) and karyotypic similarity with species of related genera: taxonomic implications. Acta Zoologica Sinica 53: 285-293.

Baêta D., Lourenço A.C.C. \& Nascimento L.B. 2007. Tadpole and advertisement call of Physalaemus erythros Caramaschi, Feio \& Guimarães-Neto, 2003 (Amphibia, Anura, Leiuperidae). Zootaxa 1623 (1): 39-46. https://doi.org/10.11646/zootaxa.1623.1.2

Beçak M. L. 1968. Chromosomal analysis of eighteen species of Anura. Caryologia 21: 191-208. https://doi.org/10.1080/00087114.1968.10796299

Bokermann W.C.A. 1962. Notas sobre três espécies de Physalaemus (Amphibia, Salientia, Leptodactylidae). Anais da Academia Brasileira de Ciências 34: 563-568.

Bokermann W.C.A. 1963. Girinos de anfíbios brasileiros 2 (Amphibia, Salientia). Revista Brasileira de Biologia 23: 349- 353.

Bokermann W.C.A. 1966 Dos nuevas especies de Physalameus de Espírito Santo, Brasil (Amphibia, Leptodactylidae). Physis 26: 193-202.

Brum-Zorrilla N. \& Saez F.A. 1968. Chromosomes of Leptodactylidae (Amphibia anura). Experientia 24: 969. https://doi.org/10.1007/BF02138689

Cardoso A.J. \& Haddad C.F.B. 1985. Nova espécie de Physalaemus do grupo signiferus (Amphibia, Anura, Leptodactylidae). Revista Brasileira de Biologia 45: 33-37.

Carvalho T.R., Roberto I.J., Dias E.G., Santos R.L. \& Santos E.M. 2020. The advertisement call of Physalaemus caete Pombal \& Madureira, 1997 (Anura: Leptodactylidae: Leiuperinae), an endangered species endemic to Brazil's northern Atlantic Forest. Zootaxa 4822 (3): 439-442.

https://doi.org/10.11646/zootaxa.4822.3.9 
Center for Conservation Bioacoustics. 2011. Raven Pro: interactive sound analysis software (Version 1.4) [Computer software]. The Cornell Lab of Ornithology, Ithaca, NY. Available from http://ravensoundsoftware.com/ [accessed 30 Jul. 2021].

Center for Conservation Bioacoustics. 2019. Raven Pro: interactive sound analysis software (Version 1.) [Computer software]. The Cornell Lab of Ornithology, Ithaca, NY.

Available from http://ravensoundsoftware.com/ [accessed 08 Aug. 2021]

Ceron K. \& Santana D.J. 2017. The tadpole of Physalaemus nanus (Boulenger, 1888) (Anura, Leptodactylidae) from Southern Brazil. Zootaxa 4277 (2): 280-284.

https://doi.org/10.11646/zootaxa.4277.2.9

Charif R.A., Strickman L.M. \& Waack A.M. 2010. Raven Pro 1.4 User's Manual. The Cornell Lab of Ornithology, Ithaca, NY.

Chiaradia C. 2008. Dicionário de palavras brasileiras de origem indígena. Editora Limiar, São Paulo.

Cruz C.A.G., Nascimento L.B. \& Feio R.N. 2007. A new species of the genus Physalaemus Fitzinger, 1826 (Anura, Leiuperidae) from Southeastern Brazil. Amphibia-Reptilia 28: 457-465. https://doi.org/10.1163/156853807782152444

De Lucca E.J., Jim J. \& Foresti F. 1974. Chromosomal studies in twelve species of Leptodactylidae and one Brachycephalidae. Caryologia 27: 183-191. https://doi.org/10.1080/00087114.1974.10796573

Feller A.E. \& Hedges S.B. 1998. Molecular evidence for the early history of living amphibians. Molecular Phylogenetics and Evolution 9: 509-516. https://doi.org/10.1006/mpev.1998.0500

Fouquet A., Gilles A., Vences M., Marty C., Blanc M. \& Gemmell N.J. 2007. Underestimation of species richness in Neotropical frogs revealed by mtDNA analyses. PloS ONE 10: e1109.

https://doi.org/10.1371/journal.pone.0001109

Fouquet A., Blotto B.L., Maronna M.M., Verdade V.K., Juncá F.A., de Sá R. \& Rodrigues M.T. 2013. Unexpected phylogenetic positions of the genera Rupirana and Crossodactylodes reveal insights into the biogeography and reproductive evolution of leptodactylid frogs. Molecular Phylogenetics and Evolution 67: 445-457. https://doi.org/10.1016/j.ympev.2013.02.009

Frost D.R. 2021. Amphibian Species of the World: an Online Reference. Version 6.1 Electronic Database. Available from https://amphibiansoftheworld.amnh.org/index.php [accessed 22 Jan. 2021].

Garcia P.C.A., Vinciprova G. \& Haddad C.F.B. 2003. The taxonomic status of Hyla pulchella joaquini B. Lutz, 1968 (Anura: Hylidae), with description of tadpole, vocalization, and comments on its relationships. Herpetologica 59: 350-363. https://doi.org/10.1655/01-54

Gatto K.P., Mattos J.V., Seger K.R. \& Lourenço L.B. 2018. Sex chromosome differentiation in the frog genus Pseudis involves satellite DNA and chromosome rearrangements. Frontiers in Genetics 9: 301. https://doi.org/10.3389/fgene.2018.00301

Goloboff P.A., Farris J.S. \& Nixon K.C. 2008. TNT, a free program for phylogenetic analysis. Cladistics 24: 774-786. https://doi.org/10.1111/j.1096-0031.2008.00217.x

Gosner K.L. 1960. A simplified table for staging anuran embryo and larvae with notes on identification. Herpetologica 16: 183-190.

Graybeal A. 1997. Phylogenetic relationships of bufonid frogs and tests of alternate macroevolutionary hypotheses characterizing their radiation. Zoological Journal of the Linnean Society 119: 297-338. https://doi.org/10.1111/j.1096-3642.1997.tb00139.x

Green D.M. \& Sessions S.K. 1991. Nomenclature for chromosomes. In: Green D.M. \& Sessions S.K. (eds) Amphibian Cytogenetics and Evolution: 431-432. Academic Press, San Diego.

https://doi.org/10.1016/B978-0-12-297880-7.50021-4 
Grosjean S. 2005. The choice of external morphological characters and developmental stages for tadpolebased anuran taxonomy: a case study in Rana (Sylvirana) nigrovittata (Blyth, 1855) (Amphibia, Anura, Ranidae). Contributions to Zoology 74: 61-76. https://doi.org/10.1163/18759866-0740102005

Haddad C.F.B. \& Pombal Jr J.P. 1998. Redescription of Physalaemus spiniger (Anura: Leptodactylidae) and description of two new reproductive modes. Journal of Herpetology 32: 557-565.

https://doi.org/10.2307/1565210

Haddad C.F.B. \& Sazima I. 2004 A new species of Physalaemus (Amphibia; Leptodactylidae) from the Atlantic forest in southeastern Brazil. Zootaxa 479 (1): 1-12. https://doi.org/10.11646/zootaxa.479.1.1

Hall T.A. 1999. BioEdit: a user-friendly biological sequence alignment editor and analysis program for Windows 95/98/NT. Nucleic Acids Symposium Series 41: 95-98.

Hartmann M.T., Giasson L.O.M., Hartmann P.A. \& Haddad C.F.B. 2005. Visual communication in Brazilian species of anurans from the Atlantic forest. Journal of Natural History 39: 1675-1685.

https://doi.org/10.1080/00222930400008744

Hedges S.B. 1994. Molecular evidence for the origin of birds. Proceedings of the National Academy of Sciences of the United States of America 91: 2621-2624. https://doi.org/10.1073/pnas.91.7.2621

Hepp F. \& Pombal J.P.Jr. 2020. Review of bioacoustical traits in the genus Physalaemus Fitzinger, 1826 (Anura: Leptodactylidae: Leiuperinae). Zootaxa 4725 (1): 1-106.

https://doi.org/10.11646/zootaxa.4725.1.1

Heyer W.R. 1985. New species of frogs from Boracéia, São Paulo, Brazil. Proceedings of the Biological Society of Washington 98: 657-671.

Heyer W.R. \& Wolf A.J. 1989. Physalaemus crombiei (Amphibia: Leptodactylidae), a new frog species from Espírito Santo, Brazil, with comment on the P. signifer group. Proceedings of the Biological Society of Washington 102: 500-506.

Heyer W.R., Rand A.S., Cruz C.A.G., Peixoto O.L. \& Nelson C.E. 1990. Frogs of Boracéia. Arquivos de Zoologia 31: 231-410.

Hödl W. \& Amézequita A. 2001. Visual signaling in anuran amphibians. In: Ryan M.J. (ed.) Anuran Communication: 121-141. Smithsonian Institution Press, Washington.

IUCN Standards and Petitions Committee. 2019. Guidelines for Using the IUCN Red List Categories and Criteria. Version 14. Prepared by the Standards and Petitions Committee.

Available from http://www.iucnredlist.org/documents/RedListGuidelines.pdf [accessed 30 Jul. 2021].

Katoh K., Rozewicki J. \& Yamada K.D. 2019. MAFFT online service: multiple sequence alignment, interactive sequence choice and visualization. Briefings in Bioinformatics 20: 1160-1166.

https://doi.org/10.1093/bib/bbx108

King M. 1980. C-banding studies in Australian hylid frogs: secondary constriction structure and the concept of euchromatin transformation. Chromosoma 80: 191-207. https://doi.org/10.1007/BF00286300

King M. \& Rofe R. 1976. Karyotypic variation in the Australian gecko Phyllodactylus marmoratus (Gray) (Gekkonidae: Reptilia). Chromosoma 54: 75-87. https://doi.org/10.1007/BF00331835

Kirov I., Khrustaleva L., Van Laere K., Soloviev A., Meeus S., Romanov D. \& Fesenko I. 2017. DRAWID: user-friendly java software for chromosome measurements and idiogram drawing. Comparative Cytogenetics 11 (4): 747-757. https://doi.org/10.3897/compcytogen.v11i4.20830

Köhler J., Jansen M., Rodríguez A., Kok P.J.R., Toledo L.F., Emmrich M., Glaw F., Haddad C.F.B., Rödel M.-O. \& Vences M. 2017. The use of bioacoustics in anuran taxonomy: theory, terminology, methods and recommendations for the best practice. Zootaxa 4251 (1): 1-124.

https://doi.org/10.11646/zootaxa.4251.1.1 
LEAL F. et al., A new species of the Physalaemus signifer clade

Kumar S., Stecher G. \& Tamura K. 2016. MEGA7: Molecular Evolutionary Genetics Analysis, version 7.0 for bigger datasets. Molecular Biology and Evolution 33: 1870-1874.

https://doi.org/10.1093/molbev/msw054

Lavilla E.O. \& Scrocchi G.J. 1986. Morfometría larval de los géneros de Telmatobiinae (Anura: Leptodactylidae) de Argentina y Chile. Physis 44: 39-43.

Leal F., Leite F.S.F., Costa W.P., Nascimento L.B., Lourenço L.B. \& Garcia P.C.A. 2020. Amphibians from Serra do Cipó, Minas Gerais, Brasil. VI: a new species of the Physalemus deimaticus Group (Anura, Leptodactylidae). Zootaxa 4766 (2): 306-330. https://doi.org/10.11646/zootaxa.4766.2.3

Leite F.S.F., Pezzuti T.L. \& Garcia P.C.A. 2012. ANew species of the Bokermannohyla pseudopseudis group from the Espinhaço Range, Central Bahia, Brazil (Anura: Hylidae). Herpetologica 68: 401-409. https://doi.org/10.1655/HERPETOLOGICA-D-11-00006.1

Lins A.C.R., Magalhães R.F., Costa R.N., Brandão R.A., Py-Daniel T.R., Miranda N.E.O., Maciel N.M., Nomura F. \& Pezzuti T.L. 2018. The larvae of two species of Bokermannohyla (Anura, Hylidae, Cophomantini) endemic to the highlands of central Brazil. Zootaxa 4527 (4): 501-520.

https://doi.org/10.11646/zootaxa.4527.4.3

Lomolino M.V. 2001. Elevation gradients of species-density: historical and prospective views. Global Ecology and Biogeography 10: 3-13. https://doi.org/10.1046/j.1466-822x.2001.00229.x

Lourenço L.B., Nascimento J.A.A., Andrade V.C., Rossa-Feres D.C. \& Recco-Pimentel S.M. 2006. Chromosomal analysis of the leptodactylids Pleurodema diplolistris and Physalaemus nattereri (Amphibia, Anura). Amphibia-Reptilia 27: 481-489. https://doi.org/10.1163/156853806778877103

Lourenço L.B., Targueta C.P., Baldo D., Nascimento J., Garcia P.C.A., Andrade G.V., Haddad C.F.B. \& Recco-Pimentel S.M. 2015. Phylogeny of frogs from the genus Physalaemus (Anura, Leptodactylidae) inferred from mitochondrial and nuclear gene sequences. Molecular Phylogenetics and Evolution 92: 204-216. https://doi.org/10.1016/j.ympev.2015.06.011

Lyra M.L., Haddad C.F.B. \& Azeredo-Espin A.M.L. 2017. Meeting the challenge of DNA barcoding Neotropical amphibians: Polymerase chain reaction optimization and new COI primers. Molecular Ecology Resources 17: 966-980. https://doi.org/10.1111/1755-0998.12648

Milani M., Cassini C.S., Recco-Pimentel S.M. \& Lourenço L.B. 2011. Karyotypic data detect interpopulational variation in Physalaemus olfersii and the first case of supernumerary chromosome in the genus. Animal Biology Journal 2: 21-28.

Nascimento L.B., Carvalho Jr. R.R., Wogel H., Fernandes D.S. \& Feio R.N. 2001. Reprodução e descrição do girino de Physalaemus rupestris Caramaschi, Carcerelli \& Feio, 1991 (Amphibia, Anura, Leptodactylidae). Boletim do Museu Nacional, Nova Série, Série Zoologia 450: 1-10.

Nascimento L.B., Caramaschi U. \& Cruz C.A.G. 2005. Taxonomic review of the species group of the genus Physalameus Fitzinger, 1826 with revalidation of the genera Engystomops Jimenez-de-la-Espada, 1872 and Eupemphix Steindachner, 1836 (Amphibia, Anura, Leptodactylidae). Arquivos do Museu Nacional 63: 297-320.

Nylander J.A.A. 2004. MrModeltest v2. Uppsala University: Program distributed by the author. Evolutionary Biology Centre.

Palumbi S.R., Martin A., Romano S., McMillan W.O., Stice L. \& Grabowski G. 2002. The Simple Fool's Guide to PCR Version 2.0. University of Hawaii, Honolulu.

Pimenta B.V.S., Cruz C.A.G. \& Silvano D.L. 2005. A new species of the genus Physalaemus Fitzinger, 1826 (Anura, Leptodactylidae) from the Atlantic Rain Forest of southern Bahia, Brazil. Amphibia-Reptilia 26: 201-210. https://doi.org/10.1163/1568538054253483 
Pombal J.P. \& Madureira C.A. 1997. A new species of Physalaemus (Anura: Leptodactylidae) from the Atlantic rain forest of northeastern Brazil. Alytes 15: 105-112.

Provete D.B., Garey M.V., Dias N.Y.N. \& Rossa-Feres D.C. 2011. The Tadpole of Physalaemus moreirae (Anura: Leiuperidae). Herpetologica 67 (3): 258-270.

https://doi.org/10.1655/HERPETOLOGICA-D-11-00004.1

Provete D.B., Garey M.V., Toledo L.F., Nascimento J., Lourenço L.B., Rossa-Feres D.C. \& Haddad C.F.B. 2012. Redescription of Physalaemus barrioi (Anura: Leiuperidae). Copeia 2012: 507-518.

https://doi.org/10.1643/CH-10-142

Quinderé Y.R., Lourenço L.B., Andrade G.V., Tomatis C., Baldo D. \& Recco-Pimentel S.M. 2009. Polytypic and polymorphic cytogenetic variations in the widespread anuran Physalaemus cuvieri (Anura, Leiuperidae) with emphasis on nucleolar organizing regions. Biological Research 42: 79-92.

https://doi.org/10.4067/S0716-97602009000100008

Rahbek C. 1995. The elevational gradient of species richness: a uniform pattern? Ecography 18: 200-205. https://doi.org/10.1111/j.1600-0587.1995.tb00341.x

Rambaut A., Suchard M.A., Xie D. \& Drummond A.J. 2014. Tracer v1.6.

Available from http://beast.bio.ed.ac.uk/Tracer [accessed 30 Jul. 2021].

Ronquist F., Teslenko M., van der Mark P., Ayres D. L., Darling A., Höhna S., Larget B., Liu L., Suchard M.A. \& Huelsenbeck J.P. 2011. MrBayes 3.2: Efficient Bayesian phylogenetic inference and model choice across a large model space. Systematics Biology 61: 1-4. https://doi.org/10.1093/sysbio/sys029

Rosenthal G.G., Rand A.S. \& Ryan M.J. 2004. The vocal sac as a visual cue in anuran communication: an experimental analysis using video playback. Animal Behaviour 68 (1): 55-58.

https://doi.org/10.1016/j.anbehav.2003.07.013

Ruggeri J., Ferreira C.P. \& Weber L.N. 2011. The tadpole of Physalaemus angrensis Weber, Gonzaga, and Carvalho-e-Sila, 2005 (Anura, Leptodactyllidae). South American Journal of Herpetology 6 (3): 229-233. https://doi.org/10.2994/057.006.0310

Ruggeri J. \& Weber L.N. 2012. A survey of the internal oral features and external morphology of Physalaemus larvae (Anura, Leptodactylidae). Zootaxa 3200 (1): 1-26. https://doi.org/10.11646/zootaxa.3200.1.1

Santos M.T.T., Magalhães R.F., Lyra M.L., Santos F.R., Zaher H., Giasson L.O.M., Garcia P.C.A., Carnaval A.C. \& Haddad C.F.B. 2020. Multilocus phylogeny of Paratelmatobiinae (Anura: Leptodactylidae) reveals strong spatial structure and previously unknown diversity in the Atlantic Forest hotspot. Molecular Phylogenetics and Evolution 148: 106819. https://doi.org/10.1016/j.ympev.2020.106819

Safford H.D. 2007. Brazilian páramos IV. Phytogeography of the campos de altitude. Journal of Biogeography 34: 1701-1722. https://doi.org/10.1111/j.1365-2699.2007.01732.x

Schacht M.C. \& McBrayer L.D. 2009. A method for constructing an adjustable platform to obtain lateral photographs of larval anurans. Herpetological Review 40: 303-304.

Schmid M., Olert J. \& Klett C. 1979. Chromosome banding in Amphibia. III. Sex chromosomes in Triturus. Chromosoma 71: 29-55. https://doi.org/10.1007/BF00426365

Schneider C.A., Rasband W.S. \& Eliceiri K.W. 2012. NIH Image to ImageJ: 25 years of image analysis. Nature Methods 9: 671-675. https://doi.org/10.1038/nmeth.2089

Silva A.P.Z., Júnior F.A.B., Haddad C.F.B. \& Kasahara C. 2000. Karyotypes and nucleolus organizer regions in four species of the genus Physalaemus (Anura, Leptodactylidae). Iheringia 88: 159-164. 
LEAL F. et al., A new species of the Physalaemus signifer clade

Silva E.T., Peixoto M.A.A., Leite F.S.F., Feio R.N. \& Garcia P.C.A. 2018. Anuran distribution in a highly diverse region of the Atlantic Forest: the Mantiqueira mountain range in southeastern Brazil. Herpetologica 74: 294-305. https://doi.org/10.1655/Herpetologica-D-17-00025.1

Titus T.A. 1992. A Phylogenetic Analysis of the Desmognathinae (Caudata: Plethodontidae): Evolutionary Patterns Inferred from Mitochondrial DNA Sequences. PhD. thesis, University of Kansas, Lawrence.

Toledo L.F., Martins I.A., Bruschi D.P., Passos M.A., Alexandre C. \& Haddad C.F.B. 2015. The anuran calling repertoire in the light of social context. Acta Ethologica 18: 87-99.

https://doi.org/10.1007/s10211-014-0194-4

Tomatis C.G., Baldo D., Kolenc F. \& Borteiro C. 2009. Chromosomal variation in the species of the Physalaemus henselii group (Anura, Leiuperidae). Jounal of Herpetology 43: 555-560.

https://doi.org/10.1670/08-122R1.1

Vasconcelos M.F. \& Rodrigues M. 2010. Patterns of geographic distribution and conservation of the open-habitat avifauna of southeastern Brazilian mountaintops (campos rupestres and campos de altitude). Papéis Avulsos de Zoologia 50 (1): 1-29. https://doi.org/10.1590/S0031-10492010000100001

Vittorazzi S.E., Quinderé Y.R.S.D., Recco-Pimentel S.M., Tomatis C., Baldo D., Lima J.R.F., Ferro J.M., Lima J.D. \& Lourenço L.B. 2014. Comparative cytogenetics of Physalaemus albifrons and Physalaemus cuvieri species groups (Anura, Leptodactylidae). Comparative Cytogenetics 8 (2): 103-123.

https://doi.org/10.3897/compcytogen.v8i2.6414

Vittorazzi S.E., Lourenço L.B., Solé M., Faria R.G. \& Recco-Pimentel S.M. 2016. Chromosomal analysis of Physalaemus kroyeri and Physalaemus cicada (Anura, Leptodactylidae). Comparative Cytogenetics 10 (2): 311-323. https://doi.org/10.3897/CompCytogen.v10i2.9319

Walker M., Lyra M.L. \& Haddad C.F.B. 2018. Phylogenetic relationships and cryptic species diversity in the Brazilian egg-brooding tree frog, genus Fritziana Mello-Leitão 1937 (Anura: Hemiphractidae). Molecular Phylogenetics and Evolution 123: 59-72. https://doi.org/10.1016/j.ympev.2018.02.012

Watters J.L., Cummings S.T., Flanagan R.L. \& Siler C.D. 2016. Review of morphometric measurements used in anuran species descriptions and recommendations for a standardized approach. Zootaxa 4072 (4): 477-495. https://doi.org/10.11646/zootaxa.4072.4.6

Weber L.N. \& Carvalho-e-Silva S.P. 2001. Descrição da larva de Physalaemus signifer (Girard, 1853) (Amphibia, Anura, Leptodactylidae) e informações sobre a reprodução e a distribuição geográfica da espécie. Boletim do Museu Nacional, Nova Série, Série Zoologia 462: 1-6.

Weber L.N., Gonzaga L.P. \& Carvalho-e-Silva S.P. 2006. A new species of Physalaemus Fitzinger, 1826 from the lowland Atlantic Forest of Rio de Janeiro state, Brazil (Amphibia, Anura, Leptodactylidae). Arquivos do Museu Nacional 63: 677-684.

Zornosa-Torres C., Augusto-Alves G., Lyra M.L., Silva J.C., Garcia P.C.A., Leite F., Verdade V., Rodrigues M.T., Gasparini J.L., Haddad C.F.B. \& Toledo L.F. 2020. Anurans of the Caparaó National Park and surroundings, southeast Brazil. Biota Neotropica 20 (3): e20190882.

https://doi.org/10.1590/1676-0611-bn-2019-0882

Manuscript received: 12 March 2021

Manuscript accepted: 21 June 2021

Published on: 26 August 2021

Topic editor: Rudy C.A.M. Jocqué

Desk editor: Radka Rosenbaumová 
Printed versions of all papers are also deposited in the libraries of the institutes that are members of the EJT consortium: Muséum national d'histoire naturelle, Paris, France; Meise Botanic Garden, Belgium; Royal Museum for Central Africa, Tervuren, Belgium; Royal Belgian Institute of Natural Sciences, Brussels, Belgium; Natural History Museum of Denmark, Copenhagen, Denmark; Naturalis Biodiversity Center, Leiden, the Netherlands; Museo Nacional de Ciencias Naturales-CSIC, Madrid, Spain; Real Jardín Botánico de Madrid CSIC, Spain; Zoological Research Museum Alexander Koenig, Bonn, Germany; National Museum, Prague, Czech Republic.

\section{Supplementary files}

Supp. file 1. Margin of the Lagoa da Sombra, type locality of Physalaemus araxa sp. nov., the site where 24 hours of vocal activity was recorded; arrow indicates the autonomous recorder.

https://doi.org/10.5852/ejt.2021.764.1475.4907

Supp. file 2. Identification, voucher number, and locality of the specimens and GenBank accession numbers of all the DNA sequences included in the phylogenetic analyses.

https://doi.org/10.5852/ejt.2021.764.1475.4909 
LEAL F. et al., A new species of the Physalaemus signifer clade

\section{APPENDIX I}

Adult specimens examined (all from Brazil)

Physalaemus angrensis $(\mathrm{n}=3)$

RIO DE JANEIRO: Holotype: Angra dos Reis: MNRJ 35066. Paratypes: Angra dos Reis: MNRJ 35064 , 35065 .

Physalaemus atlanticus $(\mathrm{n}=32)$

SÃO PAULO: São Sebastião: CFBH 38802. Paratypes: Ubatuba: MNRJ 35115-35118; ZUEC 620, 2617. Topotypes: Ubatuba: ZUEC 2264, 2618, 18240, 18243, 18306, 18307, 20502, 20633, 20634, 20636-20640, 21912, 21916, 21938, 21940; CFBH 1503, 2107, 4310, 4311, 4321, 4566, 7918.

Physalaemus bokermanni $(\mathrm{n}=17)$

SÃO PAULO: Bertioga: UFMG 7169; ZUEC 17448. Cubatão: CFBH 12507. São Bernardo do Campo: CFBH 38016, 38024. São Sebastião: CFBH 9766, 12897, 38842, 38843. São Paulo: ZUEC 18208, 18209.

Holotype: Santo André: MZUSP 59551. Paratypes: Santo André: ZUEC 4520, 4521. Topotypes: Santo André: ZUEC 6843-6845; CFBH 6011.

Physalaemus caete $(\mathrm{n}=8)$

ALAGOAS: Holotype: Passo de Camaragibe: MNRJ 9803. Paratypes: Passo de Camaragibe: MNRJ 9801-9805, 9848-9850.

Physalaemus camacan $(\mathrm{n}=30)$

BAHIA: Camacan: ZUEC 20915, 20916. Ilhéus: CFBH 27702, 34075, 35729, 39421; ZUEC 1746617477. Itacaré: ZUEC 16634, 17478, 17479. Porto Seguro: CFBH 32104. Uruçuca: CFBH 32342. Holotype: Una: MNRJ 33337. Paratypes: Una: MNRJ 33338-33341. Topotypes: Una: CFBH 23679, 23680.

Physalaemus claptoni $(\mathrm{n}=29)$

MINAS GERAIS: Holotype: Santana do Riacho: UFMG 16784. Paratypes: Santana do Riacho: UFMG 5418-5423, 5585, 16773-16783, 16785-16792. Topotypes: Santana do Riacho: UFMG 10120, 12999 13000 .

Physalaemus crombiei $(\mathrm{n}=68)$

ESPÍRITO SANTO: Aracruz: ZUEC 9712, 9713, 11370, 11375; MNRJ 65279-65299. Mimoso do Sul: MNRJ 61610-61617, 66331-66334. Vitória: UFMG 8229, 8233, 8234, 8244, 8247, 8257. Holotype: Santa Teresa: MZUSP 66252. Topotypes: Santa Teresa: MNRJ 38414, 38415, 84082, 84083; UFMG 13010, 13023, 13046, 13107, 13108, 13149, 13715-13728.

Physalaemus deimaticus $(\mathrm{n}=66)$

MINAS GERAIS: Diamantina: UFMG 9596-9617, 20125-20130; ZUEC 21193, 22774. Santo Antônio do Itambé: UFMG 14083-14085, 14259, 14264-14266, 14861-14865. Holotype: Jaboticatubas: MNRJ 60794. Paratypes: Jaboticatubas: MNRJ 60795; ZUEC 2091. Topotypes: Jaboticatubas: UFMG 1490114906, 16767-16772, 20107-20113, 20202; ZUEC 5004.

Physalaemus erythros $(\mathrm{n}=49)$

MINAS GERAIS: Barão de Cocais: UFMG 9977, 14938-14942, 14959, 15617, 15618. Rio Acima: UFMG 19291. Santa Bárbara: UFMG 5561, 5563-5565; MZUFV 16890, 16892, 16983, 16896; MNRJ 46694, 55001, 60465-60467, 60469-60472, 70408, 70409, 72811, 72812. Holotype: Ouro Preto: MNRJ 27986. Paratypes: Ouro Preto: MNRJ 27539, 30608. Topotypes: UFMG 2668, 2751, 4983, 14675-14680, 15616, 16016, 20114-20117. 
Physalaemus irroratus $(\mathrm{n}=6)$

MINAS GERAIS: Holotype: Santa Maria do Salto: MNRJ 35124. Paratypes: Santa Maria do Salto: MNRJ 35125 -35127, 40001, 40002.

Physalaemus lateristriga $(\mathrm{n}=6)$

SANTA CATARINA: São Bento do Sul: UFMG 9837, 9853, 10175, 10468, 10470, 17398.

Physalaemus maculiventris $(\mathrm{n}=73)$

ESPÍRITO SANTO: Santa Teresa: CFBH 10813, 10814; MBML 1827, 1828, 3765, 3892, 7310. RIO DE JANEIRO: Paraty: MNRJ 2763, 12467-12470. Teresópolis: ZUEC 9118. PARANÁ: Banhado: 78803. Guaratuba: MNRJ 9945, 9976, 9977 -9990, 9992 -10020. Ponta Grossa: 24759, 24760. SANTA CATARINA: São Bento do Sul: ZUEC: 5266. SÃO PAULO: Apiaí/Iporanga: CFBH 26729, 26731, 26732. Boraceia: ZUEC 9117. São Paulo: ZUEC 947, 948. Syntype: Santo André: AL-MN 684. Topotypes: Santo André: MNRJ 24934-24937.

Physalaemus maximus $(\mathrm{n}=3)$

MINAS GERAIS: Ouro Branco: UFMG 9621, 9622, 9625.

Physalaemus moreirae $(\mathrm{n}=40)$

PARANÁ: São Mateus do Sul: CFBH 37769. SÃO PAULO: Bertioga: UFMG 2713-1715. Boraceia: ZUEC 9113. Cubatão: ZUEC 7130. Guarujá: ZUEC 15363-15369. Ilhabela: CFBH 15168; MNRJ 79954-79956. Ilha Grande: CFBH 9528. Salesópolis: ZUEC 6438, 6439. Ubatuba: CFBH 4283; ZUEC 11571. Holotype: Santos: MNRJ 464. Topotypes: Santo André: CFBH 6012, 29058, 29280, 37870; ZUEC 11393, 11394; MNRJ 79950 -79952, 92496, 92497; UFMG 9475, 9476, 9478, 9505; Santos: MNRJ 79948, 79949.

Physalaemus nanus $(\mathrm{n}=54)$

SANTA CATARINA: Arvoredo: UFMG 19541. Benedito Novo: UFMG 18836. Blumenau: UFMG 2723, 7650-7652, 18842, 18843, 18845-18847, 18849, 19512. Bombinhas: UFMG 9251. Brusque: UFMG 10074, 10076, 10078-10081. Florianópolis: UFMG 2717, 2719-2721, 4608-4616, 4640, 4641, 7090, 7091, 19686, 19687. Rancho Queimado: UFMG 2716, 2718, 6980-6988, 7057, 7136, 17181, 17184, 17185.

Physalaemus nattereri $(\mathrm{n}=7)$

GOIÁS: São João D’aliança: UFMG 11573, 11619. MINAS GERAIS: Brasilândia de Minas: UFMG 13628. Lassance: UFMG 19176, 19177. Ibiá: UFMG 12437, 12439.

Physalaemus obtectus $(\mathrm{n}=13)$

ESPÍRITO SANTO: Sooretama: ZUEC 9440, 9442, 9484. Holotype: Linhares: MZUSP 74259.

Paratypes: Linhares: MNRJ 4025, 14206, 14207; ZUEC 15300. Topotypes: Linhares: ZUEC 8598, 8599, 8997, 9777, 21831.

Physalaemus olfersii $(\mathrm{n}=3)$

MINAS GERAIS: Delfim Moreira: UFMG 18662. SÃO PAULO, Bertioga: UFMG 2740, 2742.

Physalaemus orophilus $(\mathrm{n}=7)$

MINAS GERAIS: Catas Altas: UFMG 8034, 8053. Itabira: UFMG 4999. Mariana: UFMG 3573, 3574, 9562, 10504. 
Physalaemus rupestris $(\mathrm{n}=25)$

MINAS GERAIS: Rio Preto: MZUFV 9039, 9040, UFMG 20187, 20188. Holotype: Lima Duarte: MNRJ 10551. Paratypes: Lima Duarte: MNRJ 10553, 10554. Topotypes: Lima Duarte: MNRJ 24812-24821, 24823, 46447; UFMG 13367-13370; MZUFV 4083, 4084, 6440, 6617.

Physalaemus signifer $(\mathrm{n}=60)$

MINAS GERAIS: Divino: UFMG 18591-18594. RIO DE JANEIRO: Búzios: MNRJ 82981-82990. Cachoeiras de Macacu: MNRJ 72285-72292. Itaguaí: ZUEC 5181 -5196, 5246, 8221. Topotype: Rio de Janeiro: MNRJ 55310-55313, 55315-55323, 55325-55331.

Physalaemus spiniger $(\mathrm{n}=55)$

PARANÁ: Guaraqueçaba: ZUEC 14508-14522, 16253-16258. SÃO PAULO: Cananéia: CFBH 319 , 10693, 10694. Ilha Comprida: CFBH 17121, 17819; ZUEC 14523, 14524, 14526. Iporanga: CFBH 6330; ZUEC 18081, 18082. Topotype: Iguapé: CFBH 308, 310; ZUEC 6876, 6877, 9757, 9807, 9808, 9818, 10047, 10048, 10069 -10071, 17319, 17320, 17347-17349, 17372, 17373, 24178-24180. 